
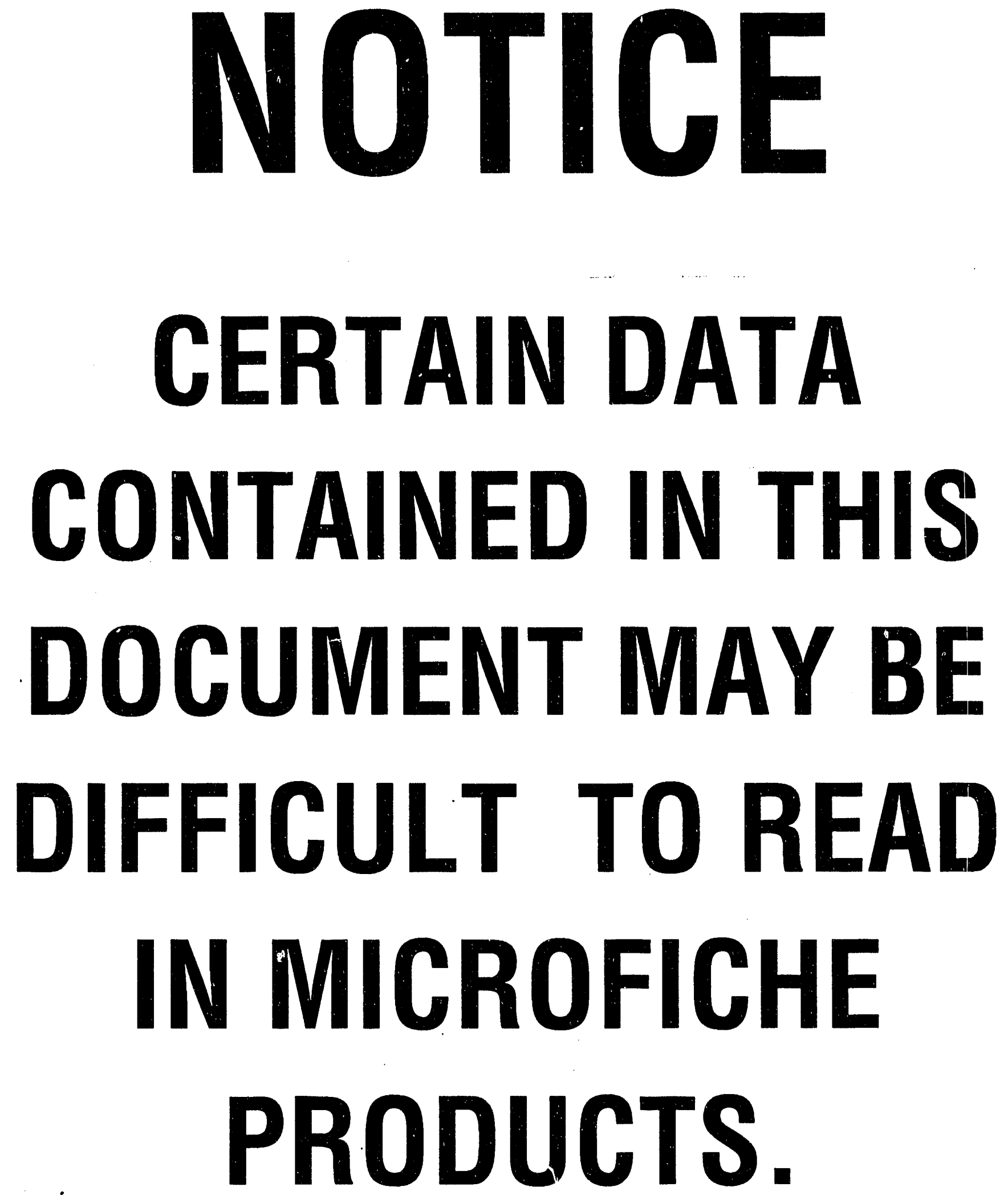


\section{DECLASGIFIED \\ the -27158}

(

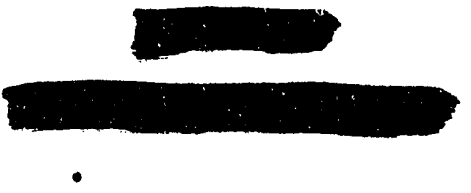

○ $\mathrm{HW}-27158$

DE93 002150

(2)

○

Th1o $d$

-

of 34

Cumeros

() 1. FW Albaugh - JP LoIts

41. M Lutton

42. KIL Mars

3. M Altman

4. JM Atwood

5. JA Ayres

6. JT Baker

7. RH Boaton

8. FW Bonol10I

9. CW Botsford

10. IP Bupp

11. NH Bushey

12. JJ Cadwoll

13. MN Carbon

14. HA Carlbers

15. AB Carbon

16. JCL Chatton

17. RG Clough

18. WR Conlor

19. DH Curt1se

20. DR de Halas

21. WR Dollollander

22. RI D1ckoman

23. JE Draloy - ANL

24. BR EIdor

25. EA Bechbach

26. EJ RIIIP

27. AM Fryar

28. S Goldsmtth

29. Oll Greager

30. AB Croninger

31. CN Gross

32. RB Hamliton - DP Crouter

43. WM Mathis

44. OB MoCullough

45. JC MoLaughlin

46. Bo Mehans

47. SE Montgomery

48. SL Noison

49. VD Nixon

50. IN O'Rorke

51. GF Oreloy - PI; Walkup

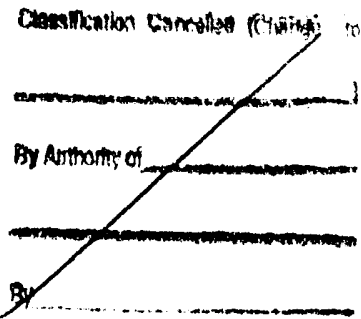

52. KF Paulor1ch - ABC-HOO०O

53. KT Porkins

54. DC P1trer

55. RH PurcelI

56. PH Rolnker

57. JE Robb - SR Stamp - RS Dunn

58. BI Rood

59. RB Rlohards

60.0 RA Rohrbacher

- 61. aM Roy

62. OWL Schall101

63. JH Sayder

64. P Thompson

65. ID Turner

66. WL Poarl

- 67. AP Vinther - RR Bloomstrand - JB Cz1rs

68. R Ward

69. JH Warren

70. WW Windohe1mer

71. JR Voloott

72. EC Hood

73. WK Woods

33. IN Haufe

34. IIL Honry

35. KW Hoss - JD Orton

36. RT Jaske

74. KIP Zuhr

75. ABC-HOO - Attni DGOSturges

76. 300 P1108

77. 700 Filos

$\odot$

37. EP Loo

38. CG Lowlo

$\bar{w}$

39. M Lowl:

40. WR Lew18

78. Jollow Copy 0

79-80 Bxtra Cop10s

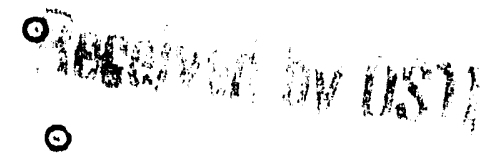

20
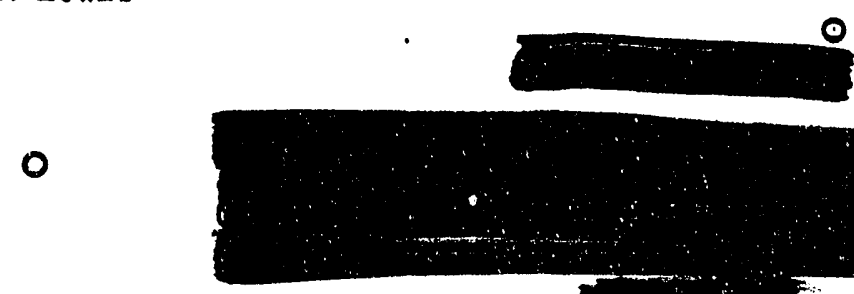

0
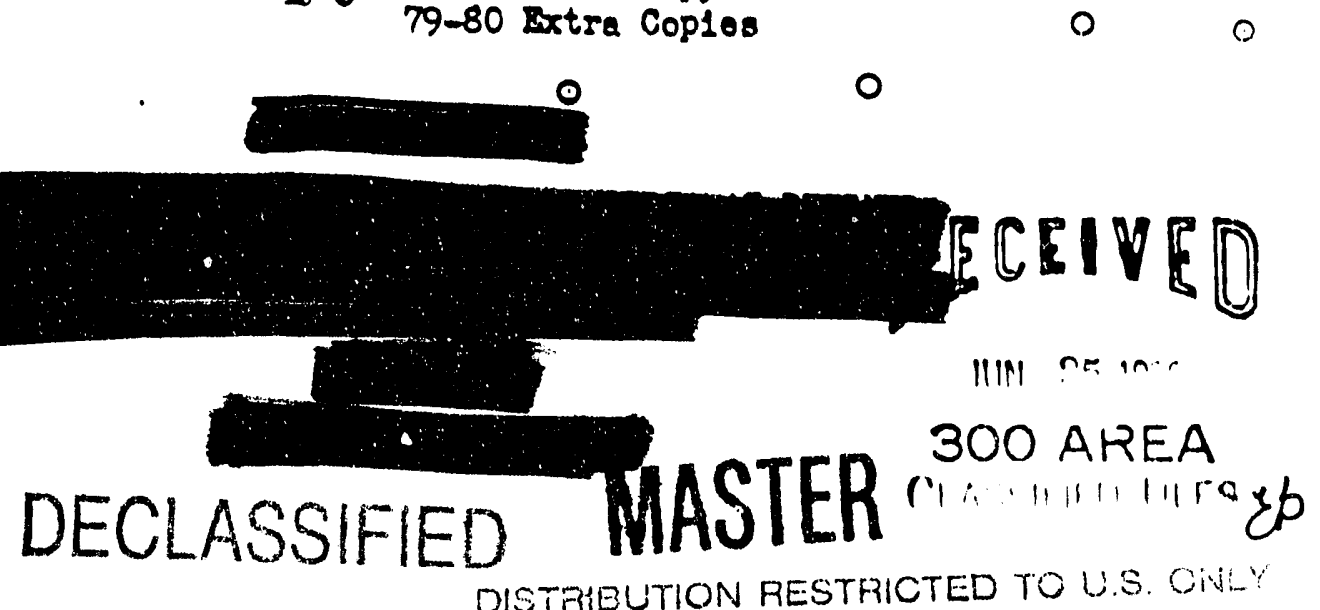

DISTRIEUTION RESTRICTED TO U.S. CINE? 


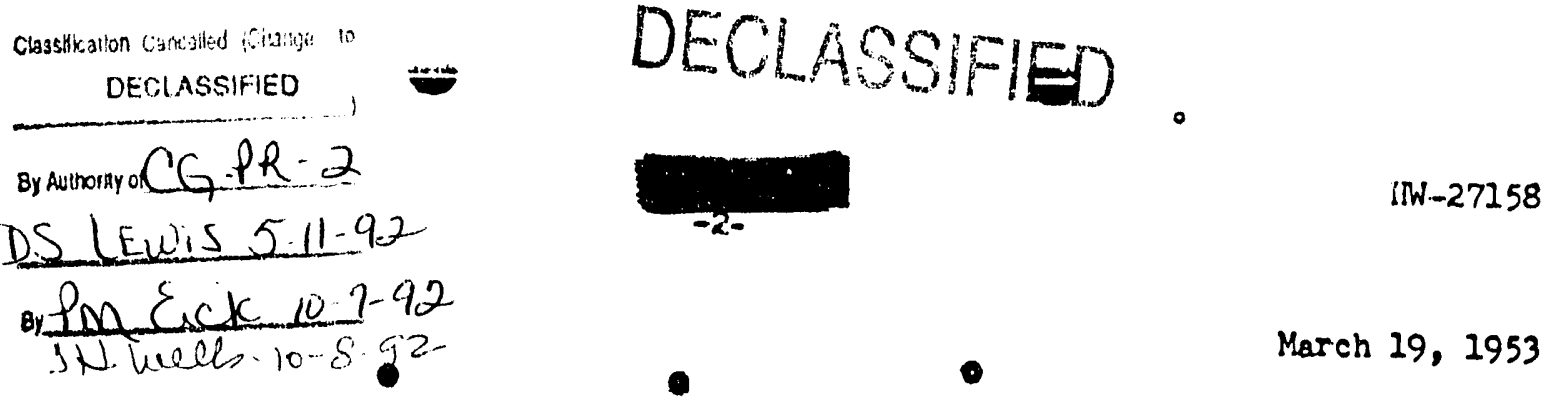

SODIUM DICHROMATE AS A PROCESS WATER ADDIFTVE, AN EVALUATION

- INTRODUCTION

-

For several years after the start-up of the Hanford P1les, 11ttle concern was folt for the quality of process water. Technsques developed by CNX and 1 mproved in the course of operating experlenge wero substantially successful for controlfing and removing pressure drop $111 \mathrm{~m} ;(1,2)$ and corrosion rates at the oarly power levels wero unf formig low and not a matter of concern, particularly olnce slugs were not exposed for more than 250 MND/ton. As power and exposuro levelo wero drastically increased, however, corrosion rates began to become serlous and now threaten to ilint future increases. The occurrence of slug ruptures became distressingly regular, and the possibility of tube leaks became a roality.

Whether or not corrosion was causing these latter problems, $1 t$ was clearly imperative to seok ways to reduce the corrosivity of the water. Furthermore, the expense of the water treatment frocedure mado it highly desirable to soek olmplifications ard to critlcally examing the necessity of all parts of the process.

It was Imodiately recognized that substantial savings could be made by the elimination of sodiun dichromate as a process water additive. Finco the ralher higis pH of process water was necessary primarlly to provent diohromato roduction, the way would then be open for roducing the pH, and 1t was hoped shat th1s would Improve in-pile corrosion and materlally roduce vater treatment costs. Inoldentally in the course of $\mathrm{pH}$ reduction, lime addition would bo oliminated, but any saving might be off set by the acid which would be required if tho $9 \mathrm{pH}$ adopted woro low onough to roquire acid adjustment. Though flow laboratory experiments did not augur woll for pH reduction, Production Test 105-453-P seemed to indicate that the olimination of dichromate would in Itsolf lower corrosion, and so dichromate addition was stopped in April, 1952. Since that time operating problems and various experiments have cast doubt on the wisdom of dichromato elimination.

There 18 a large amount of data in the project literature pertaining to tilo dichromate problem, and 1 t seemed urgent in viow of recent experiences to ro-evaluate this information to learn whether the 18sues might not bo clarified and firm conclusions reached. This document presents such a ro-ovaluation and draws conclusions which, pending the completion of experlments now in progress, will serve as a primary basis for tochnical recomendations concerning dichromate addition to process wator at all existing 100 areas and at the $100-K$ areas now under construction.

SUMPARY

A detalled reviow of the pre-start-up corrosion 11 terature show that an extremely strong omplirical case for the use of $2 \mathrm{ppm}$ eod lum dlohromato ae a ourronion inhihltor WaA lidlll up. The maln advantiage of dluhromato was Ito abll1ty to ropross tho otrong pltting tendoncles of Columbla River water in the $\mathrm{pH}$ range 6.5 to 8.0 , where uniform corrosion rates were low. From the electrochemfoal polnt of view, the use of dichromate roduced the protective value of the $72-3$ aluminum cladding on $2-S$ aluminum tubes,
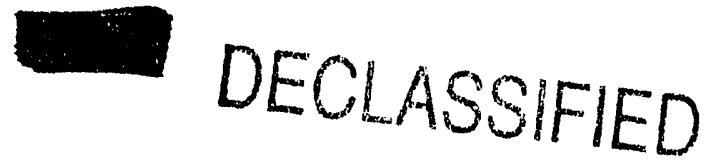


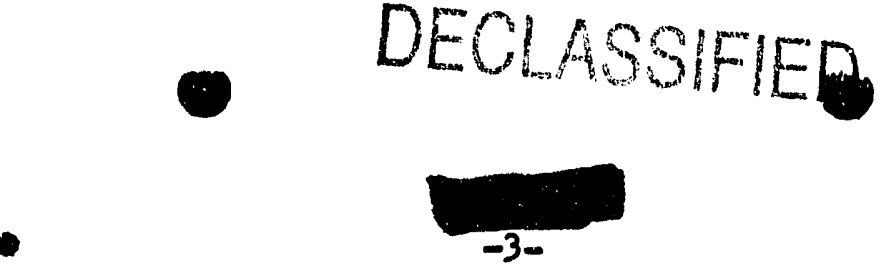

INH-2715:

but was rery effective in roducing galvanto corrosion in general, including that to bo expected from the thermogelranlo ooll formed by hot slugs and cool tube vall.

Because the scope of the dichromate elimination test vas 11 int ted, and because the results aro not unequirocal, it 1s oonoluded that the actual elimination of dichromate was not altogether justifled. Operating experience, olnce the elimination of dichromate, has been punctuated by a corlous Inorease in front tube corrosion and by the appearance of a severe slug pitting attack at F P1lo last oumer. Laboratory work strongly suggests that both problems can be oontrolled by the addition of sodium dichromate at a cexcentration of 0.2 to $2 \mathrm{ppm}$.

The ilterature also contalns strong ind1cations that excessivo reduction of d1chromate wlll not oceur at $\mathrm{pH}$ as low as 7.0 , a $\mathrm{pH}$ whlch would be very dosirablo for the much zower unfforn corrosion rate obtalnable there, but which 1s definitoly danforous, in ine absence of dichromato, due to the high probablisty of pltting.

It 18 concluded that the Horks should roturn to the use of sodium dichromato, and that offorts be made to determino the minfmum $\mathrm{P}$ H foasible for operation of th dichromato, as woll as the optimum concentration of dichromato to bo usod. Lt the same time, current exporiments should be continued to determine the feasibillty of a set of conditions under which operation without diohromate would be safe.

PART I

BASIS FOR THE ORIGINAL USE OF SODIOM DICHROMATE

The origlnal speclfleations for Hanford process water wero based on the recomendat1one dereloped from the 1ntensive CNX pllot plant scale 1arestigation. These recomendations, as presented in the Ca Final Roport (3), wero nover intexdef to represont a true optimum; but thoy did provlde a vorkable orstem which vas presumably subject to improvement under cont1 nued plant operat1or(1). Moro recently, prevalling Hanford phifosophy has tended to the position that the Cha findings might botter bo discounted $(4,5,6,7)$.

In evaluating the findings of the CNA group, 1t 18 of some 1mportance to recognifg the objectlves as woll as the limftations of the program under which thes rorked (8). In general, the pilncipal afm was to develop a water treatment method which would permit operation of the p1les, and yhich would glve a olus corrosion rato of one mil per month or less. Practicaliy, cost was not a considerations in the case of add1tives, for example, arailabll1ty wes a much moro importent factor. The vork, of necessity, was done in as atmosphere of rapldiy changing conditions, equipuent and treatments. For example, the filtration procedure was constently changlas as information developed or as equipment became avallablos illtration without coagulation, no flitration, flitration with intermittont coagulation, filtration with alum or forr10 oulfate coagliation wore all used at one time or another. Whateror proooss was in use was subjeot to conolderable manlpulation of tho prooess variables. Time, of course, was the most serfous limltations the flrst reactor was in operation less than a yoar after the actual otart of Cla tosts. Is a consequence, there vas no opportunsty to make a thorough yoar round study of the offoct of ohanglaf river water conditions on the final troatmont method.

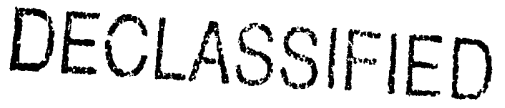




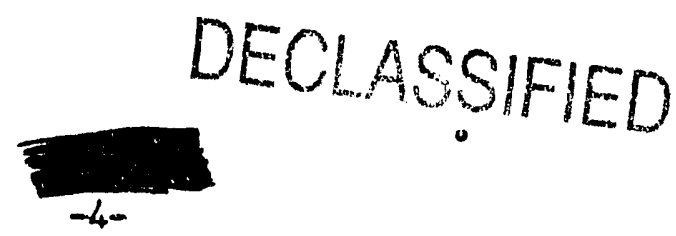

WN-27158

The recommendations dereloped by Cha for process water treatment vere as follows (3)

1. Chlorination for algae control; free $\mathrm{Cl}_{2}$ not to exceed $0.2 \mathrm{ppm}$, chlorlde not to exceed $2.0 \mathrm{ppm}$.

2. $\mathrm{pH}$ adjustment with IImo, coagulation with a comercial forrlc surfate coasilant, setiling and sitration. Tue finai pii to be in the rango 7.5 to. 7.8 .

3. Addition of 10 to $30 \mathrm{ppm}$ sodium silicate for control of film growth.

4. Fllm removal by 8011 ds purge whero necessary.

5. Addition of $2 \mathrm{ppm} \mathrm{Na}_{2} \mathrm{Cr}_{2} \mathrm{O}_{7} \cdot 2 \mathrm{H}_{2} \mathrm{O}$ to reduce corrosion.

An Important IImitation on CRX was the fallure of the1r laboratory to duplicate exactly the 100 Areas water systems, a vital factor in the film problem". This differonce lies at the root of the subsequently observed fallure of sodium silicate addition to Inhibit film growth in the plies. Aetual operating experlence has also shown coagulation with filter alum to bo moro satiafactory in controlling film than forric sulfate congulation. This can be correlated with the Cha observation, that while f1lm from (glum treated water was the rore severo, it formed in the cold, front part of the tubes $(3,9)$, whllo with ferric sulfate treatment, film formed in the rear, heated times in the 100 area plants allow a stablo steady state to be attais as before the
water enters the plles.

No such difference existed in the corrosion investigation, with the single exception of the presence of radiation. According to the CNa final roport, "acceptablo" corrosion' rates were observed in process water at a $\mathrm{pH}$ of 6.5 to 7.0 , and in the presence of $2 \mathrm{ppm}$ sodium dichromate, the rato was lower and pltting was nil. Rocently, as a more cost consolous att1 tude towards water troatwont devoloped, the nocess! ty of the

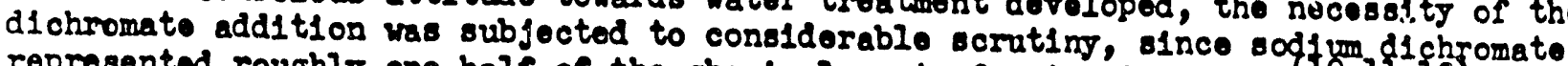
representod roughly ono-half of the chemlcal cost of water treatment $(10,1,12)$. Onfortunately, the attitude adoptgd yas a priorl that dichromate was certalnly doing no good and might even bo harmful $(1,6)$. In the offorts to ostablish thip position, frequent reforence was made to such sources is the Corrosion Handbook (13) oven though all the remarks in this work relative to dichromato inh1bition are essentially irrolerant to the Ranford systom. In the f1nel analys18, the only oystem of Interost at the Hanford Works 1s Columbia Rivor water, more or lose troatod, flowing through the pilo tubes at the operating volocitios and tomperatures*n. Results on distilled water and other natural waters cannot bs extrapolated to local oinditions without considerablo roservation.

CMX was well awaro of th1s problom. The final report statos

"It may not be possible to completely duplicato the laboratory resulto in the filter plants olnce the laboratory tests were made under ont1rely different conditions of mixing, Focoulation and filtration. For these reasons the final oraluation of the coagulants probably will have to be mado in the f1ltor planto" (Ror. 3, page 26).

* From a momorandum Prom A. Worthington to C. P. Xjddor, Novomber 23, 19431 Mr. WIIllans has urged upon mo the dosirability of our taking the atf1 tude that wo do no water treatmont, oron Plocoulation, that is not of proved relue. The experlments that jou alroady have underway are
in accordance with this".

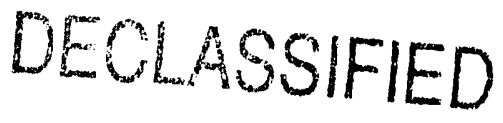




\section{OBSPRVATIONS ON DICHROMATE INHIBITION}

In the course of varlous discussions on the merlts of dichromate addition, the sugges. tion was made that the actual CNS data did not justify the concluolons drawn in the inal report. Pinally, in reference 4 , it was stated?

"There are no date in the Cad test runs which show that diohramata in the rasge of $1-20$ ppm does reduce corrosion. The followlng tablo summarizes the results of CNX test runs of 100 or more hours duration in whlch uninhibitod vater, dichromate treated water, and sodicm silicate treated water were tested" (see F1gure I).

On the other hand, ors Pinal Report states:

Marked Inhibition of corrosion was observed in al ins in which dichromate was lised. The rango covered was $1-20 \mathrm{ppm}$, although 11 ttle correlation was obtalned between the amount added and corrosion. Most data were obtained with a 2 ppm addition and showed an orerall penetration of less than one-hals that which non-inhlbited water would show under similar conditions. A major advantage in using thls inhibitor lies in the nearly complete absence of pitting-type corrosion when it is used oven under conditions which normally would cause severe pitting, as for example, whon all $=1$ num is in contact with stainless oteel, particularly at high pH
$(7.5$ to 8.0$) \%$.

In view of this disagreement, it soemed pertinent to reviow the CMW weekly reports (54) and the tata therein. Th1s analysis has lead to a substantial verification of all of the sentements made in the CNS final report concorning corrosion of $2-5$ aluminum. The corresion rate did indeed decrease when dichromato was added; but what is far more important, the pltting rrequently observed throughout the pH range 6.5 to 8.0 did not occur in the presence of dichromate. In any event, below $95 \mathrm{C}$ the long time corrosion rate was below $1 \mathrm{mil} / \mathrm{mo}$. In the range $\mathrm{pH} 6.5$ to 8.0 with or without dichromate, and the only ?actor of any importance ras the incidence of pitting. Since pitting ocurred onig in the absence of dichromate, the specification of dichromate addition was eminently reasonable and desirable.

In Figures 2 and 3 are presented the pertinent CMQ data concerning the effect of dichromats on corrosion. It will be noted that the corroblon data are somewhat incomplete: this 18 associatod with the early CNA recognition that obtaining low corrosion rates was not a problem. Most of the effort of Cid was deroted to solving the film problem and preventing pitting. Since it was thought that the reduction of dichromate ty radiation would bo excessive below $\mathrm{pH} 7.5$, the deciolon to operate in the range 7.5 to $7.81 \mathrm{~mol}$ red accepting an higher inherent corposion rate in order
to obtaln the security given by dichromate agalnst pitting.

The week:y inspections recorded in the ONX reports give the impression that pH 7.5 to 8.0 :s more sovern in general than any $\mathrm{pH}$ betweon 6.5 and 7.5 , etching bolng moro rogularly sbeorvod. Thougi dichromato did provent pltting, the appoaranco of slugs exposed to tho higher pil vater was loss favorablo than those exposed in dichromate water at $\mathrm{p} / 16.5$ to 7.5 . It ohould bo pointed out that these woekly inspections convinced CMX that operation at any $\mathrm{pH}$ would be dangorous without some kind of

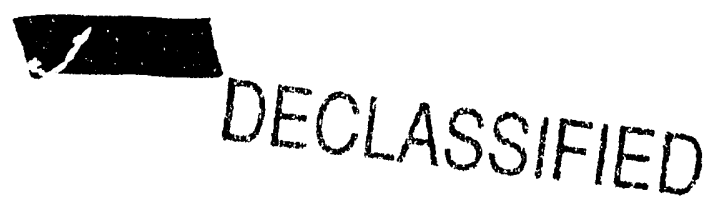




\section{DECLASSIFIED

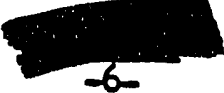

HH -27158

\section{I18ure 1"}

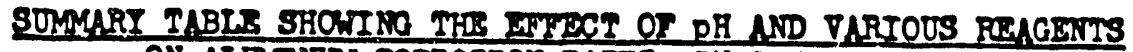

ON ALOMINUM CORROSION RUTES-IN GMR TRST RUNS

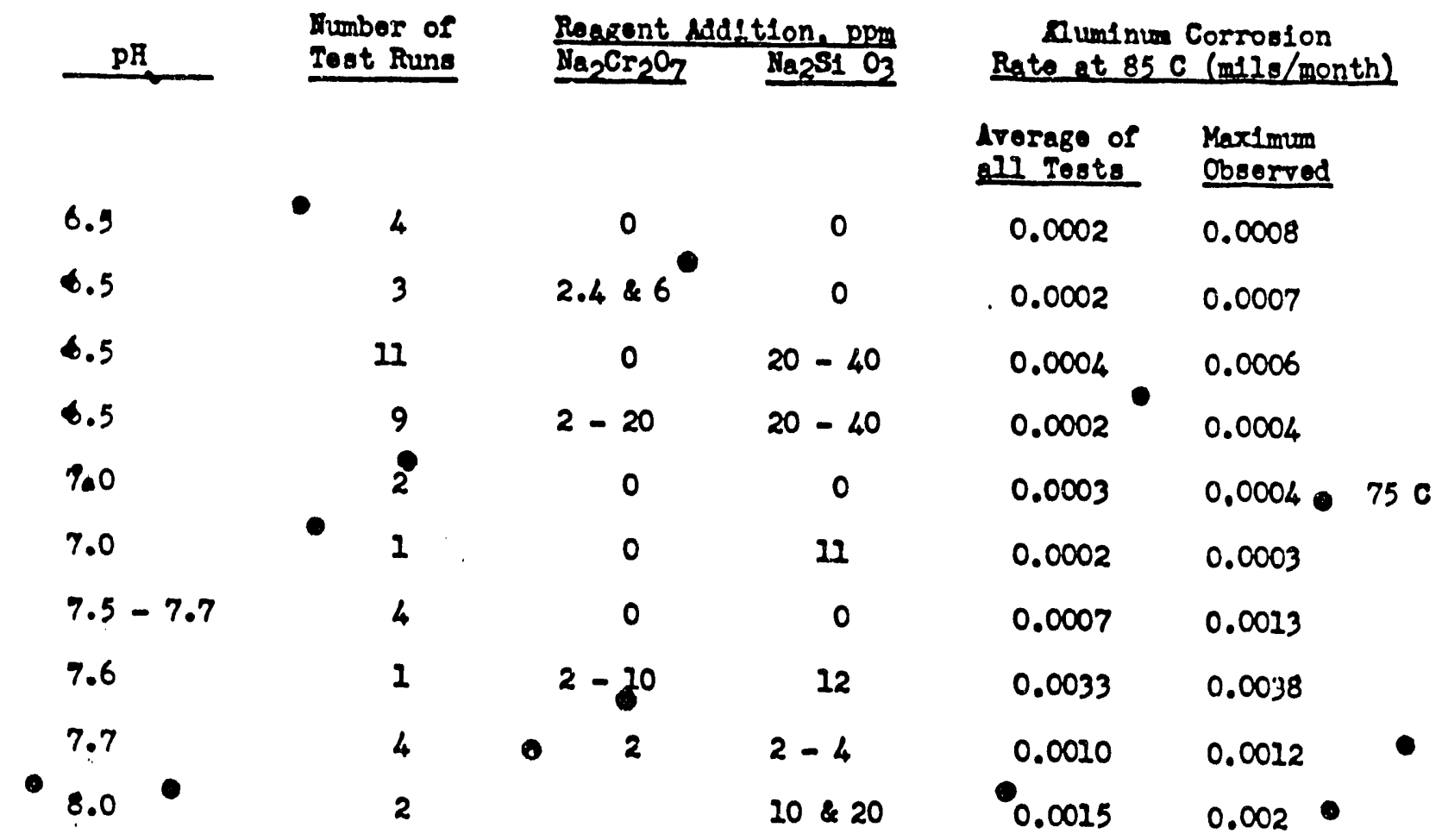

Th1s tablo 10 roproduced exactly as 1t appears In Rof. 4. F1gures 2 and 3 give a. more complote oumars of the actual cra data. Tho tablo above gitas no informetion about relatire times, al though the corrosion rate did not bocome constant t1ll will over 200 hours in axa expertence. 


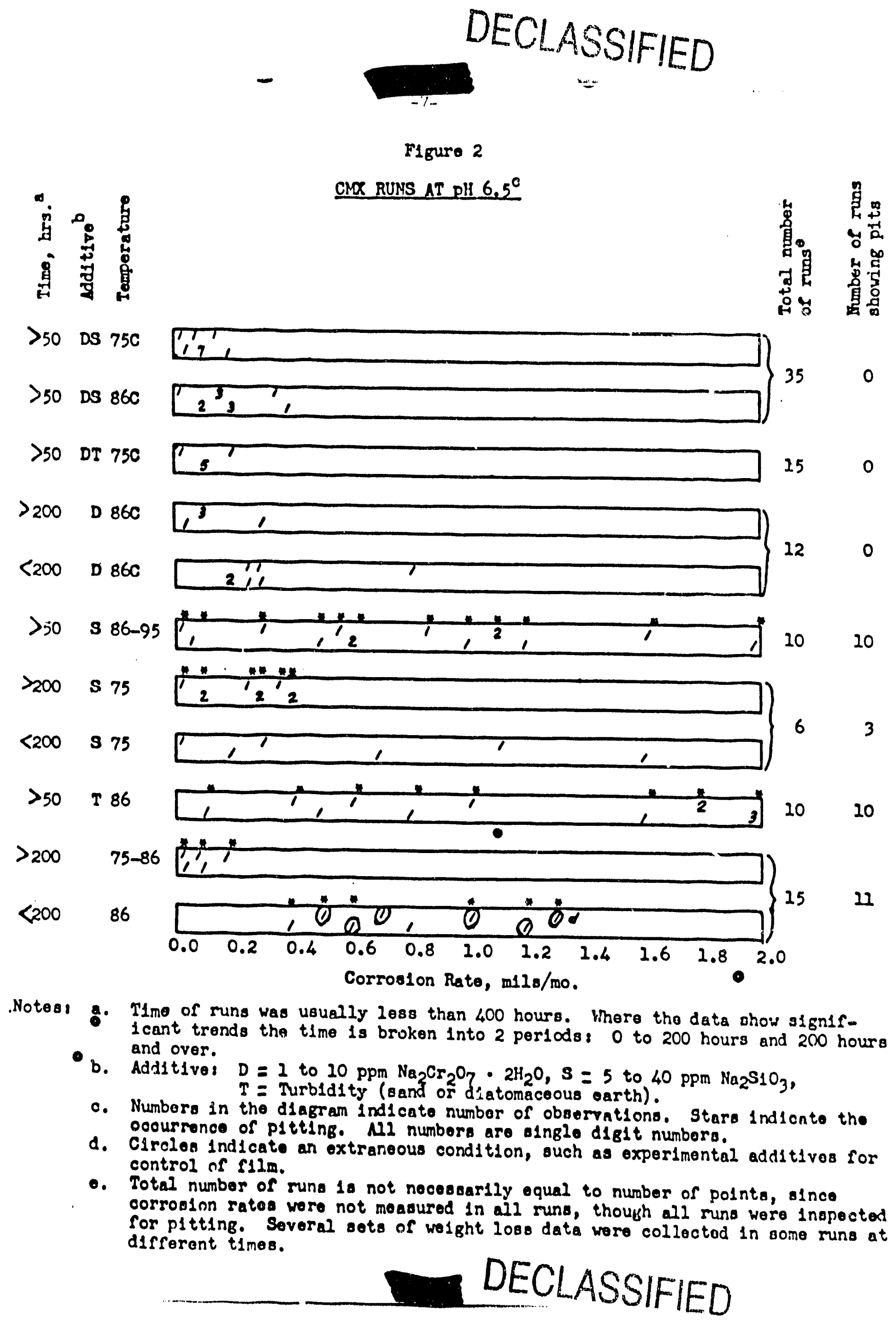




\section{ECLASSIFIED}

CMA PUNS AT pH $6.8-8.0$

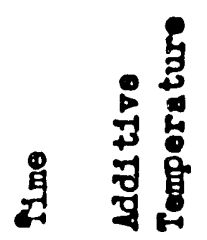

PR $6.8-7.3$

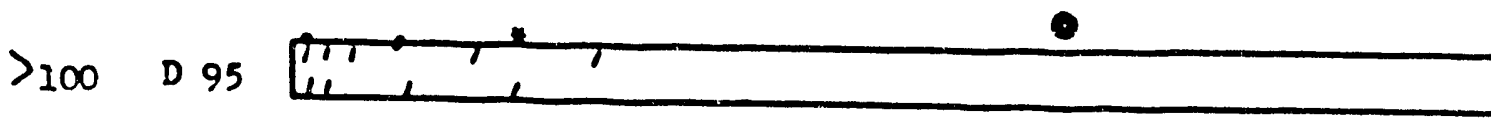

$>_{50} \mathbf{S} 86$

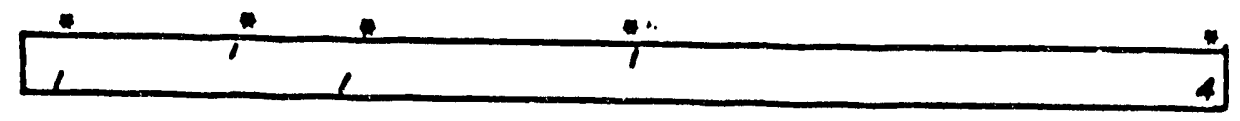

$>200 \quad \cdot 86$

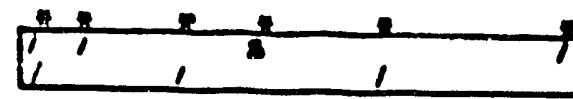

$<200$

a 86
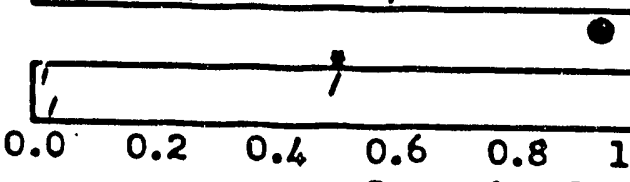

PR $7.4-8.0$

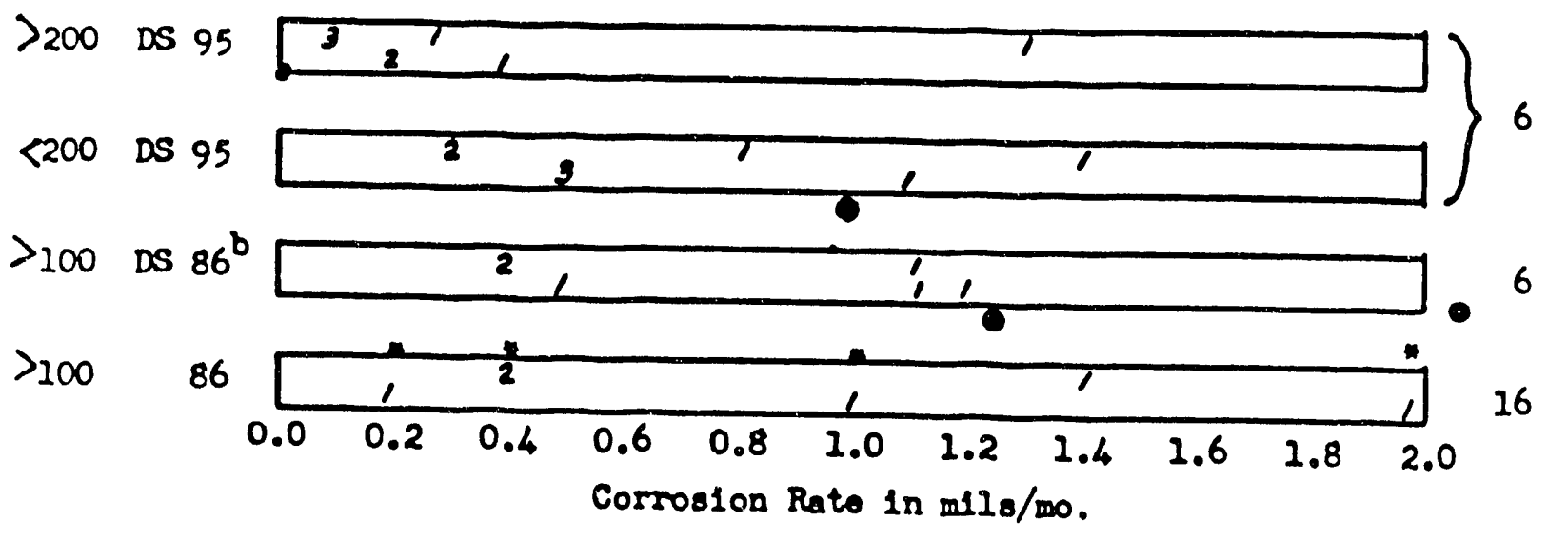

Soe notes, Figure 2.
a. Deminerallsed and deaeratod.
b. pll unadfustod, avoragod 7.7 . 
Inhibitor (cf 14 ). Of particular interest are the serles of experiments in which continuous fieds of artiflcial turbidities were studied for their film removal properties. The use of such abrasive conditions resilted in rery serlous orosioncorrosion under all conditions except the presence of 1 to $10 \mathrm{ppm}$ sodium dichromate. The latter ccmpletely stopped such attack, 80 much so that a continuous feed of 10 ppm diatomeceous earth was serfously considered as a reasonable treatrent.

The CNX work ild not Include a systematic study of the rarlation with concentration of the efflcacy of dichromete. What work was done did not show any substantial difference in behaflor in the concentration range of 1 to $20 \mathrm{Fpm}$. Though most rise were made with $2 \mathrm{ppm}$, the inftial cholce appears to have been arbitrary, although ample experience demonstrated the effectiveness of this particular concentration.

\section{OFP SITE LABOIRATORY STUDIES}

The extensive laboratory corrosion studies at the Metallurgical Laboratory in Chlcago largely substantiated the CNX findings. socording to the final report: (15)

From the corrosion tests run in this investigation, it is considered that 2-S aluminum corrosion is slight enough so that the use of the matorial should be safe in Columbla River water at:

(a) pii 6.7, tomperaturg 70 to $90 \mathrm{C}$ (and probably all lower temperatures) zero to $10^{-4}$, normal $\mathrm{H}_{2} \mathrm{O}_{2}$, zero to $25 \mathrm{ft} / \mathrm{sec}$. How rate, zero to $2 \mathrm{ppm} \mathrm{CI}$, with nooother materlals added to the water;

(b) $\mathrm{pH} 7.8$, other conditions 1dentical to (a) as long as $2 \mathrm{ppm}$ $\mathrm{Na}_{2} \mathrm{Cr}_{2} \mathrm{O}_{7} \cdot 2 \mathrm{H}_{2} \mathrm{O}$ is present as a corrosion Inbibitor, · . . 2-S aluminum corrosion rates were minimum uthin the general $\mathrm{pH}$ range 5.5 to about 7.0 with the least danger due to corrosion at $\mathrm{pH}$ near 6.5 , in the absence of corrosion inhibitors. When $2 \mathrm{ppm} \mathrm{Na}_{2} \mathrm{Cr}_{2} \mathrm{O}_{7} \cdot 2 \mathrm{H}_{2} \mathrm{O}$ was present at $\mathrm{pH} 7$ to 8 , only very mild attack occurred, wth danger of penetration of aluminum parts very slight, at temperatures from 70 to $95 \mathrm{C}$. In the absence of dichromate, areas of local attack wore found in this pH range, belleved due to local turbulence and other external factors. - - . It must be emphasized that this does not necessarily predict thate2-S aluminum may be used acconding to plans at H.E.W. at the above conditions without ang serfous corrosion. No good

- simulation has been made of the effects of radiation and externar factors such as the goometry or construction, presence of other construction materials, metal surface to volume ratio, etcn.

Other results of Interest from the Chicago investigation can be briefly summarized:

(a) The corrosion rate in uninhibited water as a rinction of $\mathrm{pH}$ is show in Figure 4 .

(b) The probability of pltting 10 a minimum at approximately pH 7.0, although pitting 18 more probable and more severe on the acld side. Though pltting at 6.5 apparently was not consldered to bo a problem, 1t was observed, particularly in longer runs.

(c) Dichromato olimlnates pitting in the rango 7.0 to 8.0 , reducos the stoopness
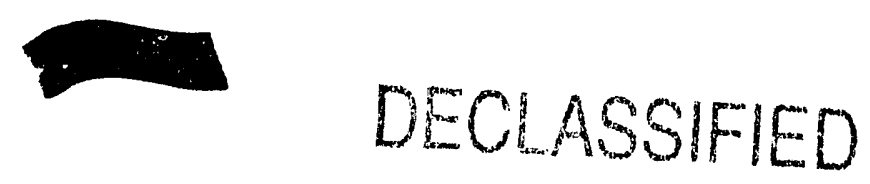


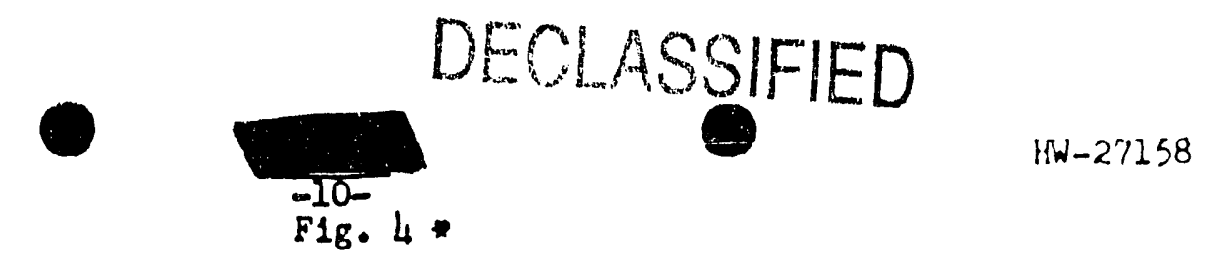

CORROSION RATE OP $2 S$ ALUMINUM AT 7OC AND

950 IN STMULATED COLUMBIA RIVER WATER

AS A FUNCTION OP pH.

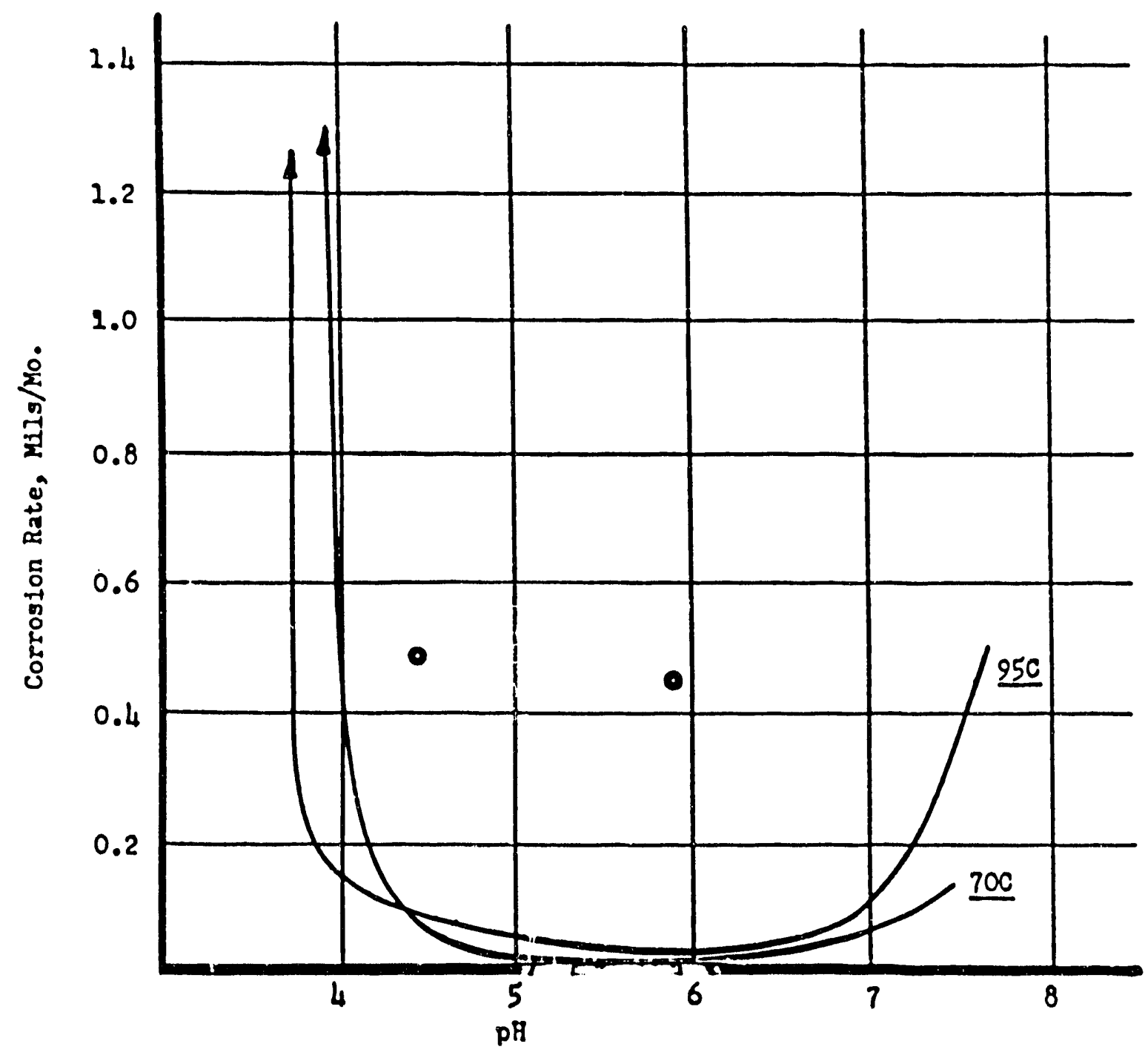

- Ref. 15

DECLASSIFIED 

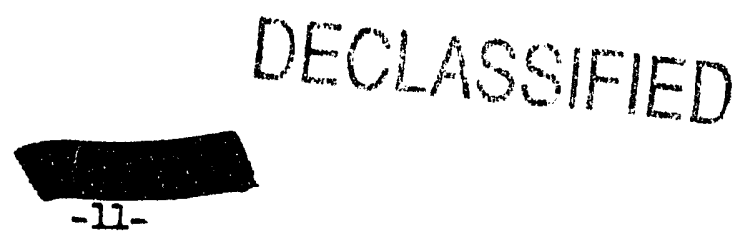

HW-27158

of the corrosion rate vorsus $\mathrm{pH}$ curve in this range, and roduces the tomperature coofflolent of the corrosion rate. Mot studied was the of fect of dichromato in the $\mathrm{pH}$ range 6.0 to 7.0 .

Another Important Investigation was carrled out at Chlcego rolat1ve to Hanford p1le problems, dealing with the plectrical aspocts of alwilmin corrosion. Th1s work, as reported by R. B. Hoxeng (16), dealt mainly with tho characterlstics of the 2-3/72-S

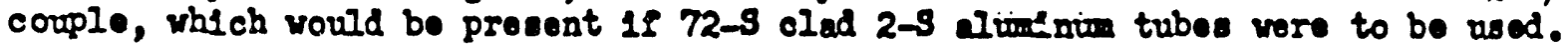

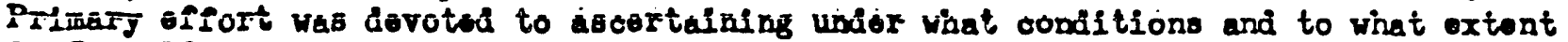
72-S would be anodle to 2-3, as must be the case if the $2-3$ is to be galvanlcally protected. S1nce a number of process rarlables, -.8. s1lloato concentration, peroxlde concentration, dichromato concentration, $\mathrm{pH}$ and tomperaturo hare a marked and Interrolated effect, attontion vas direoted primarily to a sorles of opociflo conditions. In the case of dichrowato, the not conclusion reached was that under all clreumstances of interest, the solution potentials of $2-5$ and $72-9$ are rery noarly the same. The procision of the data vas auch that the polarity of the 2-s/72-3 couplo in the presence of dichromate could not be predicted with certalnty because of the small magnt tude of the potential difference and the frequent Inotuations from one direct1on to the other. In view of these obsorvations, it was ouggested that the nse of $72-S$ aluminum clad tubes was questionable.

Another important Influence of dichromato can be sein in the effect of temperature on solution potent1als and currents at pH 6.5, as shorn in Figure 5. At room tom

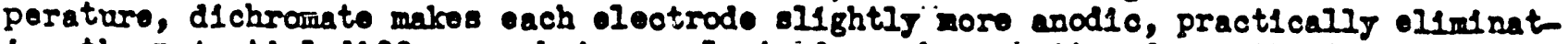
Ing the potont1al difforence between eloctrodes, wheread it reduces the tomperature ccefflcient of the solution potontial by factor noar f1it: The corrosion current 10 corrospondingly roduced, and, in the prosence of dlohronato, there is no. apparent temperature coefflolent. This offoot of dichromato 1s essentially the seme at all concentrations in the range 0.5 to $10 \mathrm{ppm}$. Onfortunatels; there are no data at higher PH's in the absence of dichromate, but those data at $\mathrm{pB} 7.0$ to 8.0 with dichromato, whlle very erratio and complicatod by other factors, ouggest that ralues of the corrosion curronts, at loast, follow olmllar tronds. In substance, the rosults saggest the use of 72-S cladding will do no great good and no groat herm from the eloctrochemlcal point of Flow.

The most Interesting aspeot of the data in Mgure 5 1s the effoct show by ilchromato on the corrosion currents, whloh wore negl1glbly siall at all temperatures measured in marked contrast to thoir' appreolablo 1ncrease with temperature when so dichromate was prosent. Though the potontial differences were emall, the fallure of the currents to incroase with temperature 1ndicates that an 1mportant aspoct of the effect of dichro-

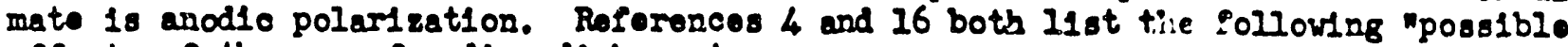
offects of the use of sodiun diahromatos

1. May change potential botwenn cathode and anode.

- 2. Will 1ncrease conductirlty of solut1on.

3. May form a F1Im on the anode wh1ch w1II decrease the anodse area, thereby Incroasing the anodic polarlzation. Thlo may rosult in local corrosion and

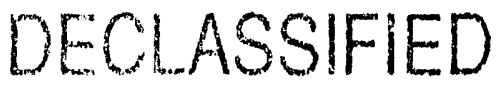




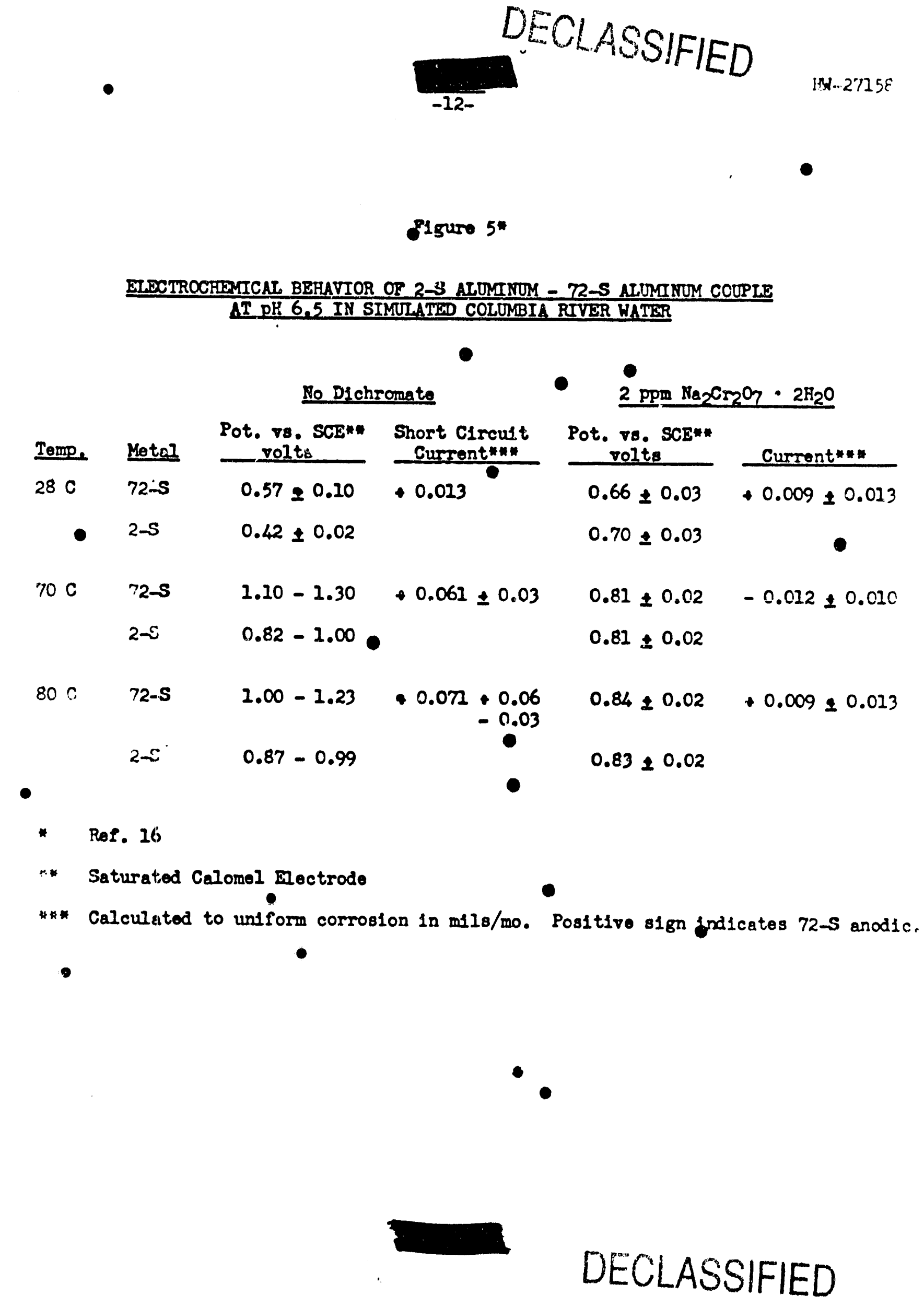




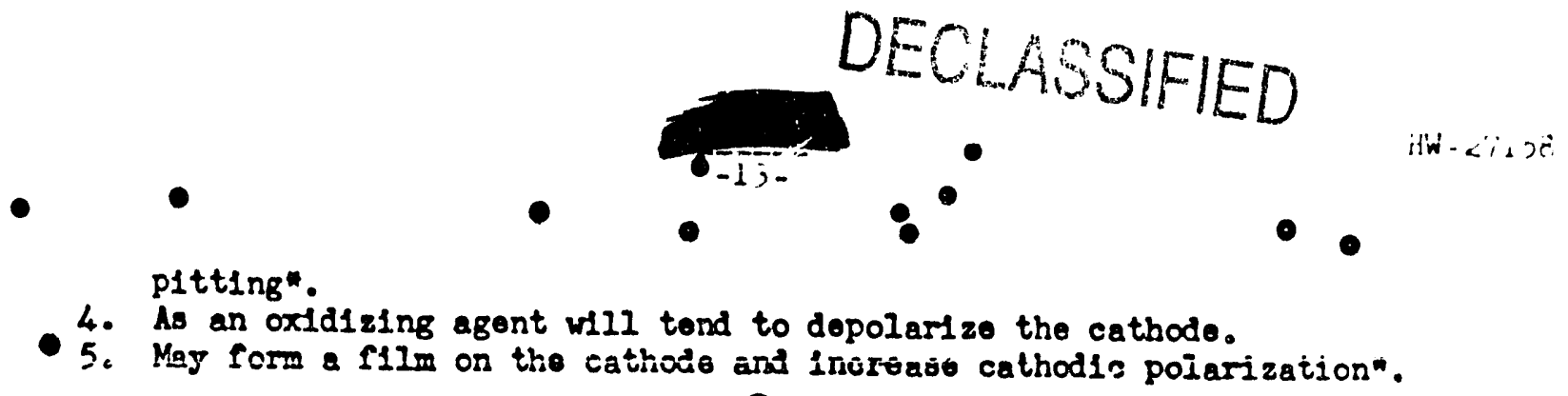

Neither reference 11 sts an obvious sixth offects

6. As an oxidizing agent will tend to polarize the anole.

In commenting on 1toms 1 to 5, ref. 4 atates:

"The first four of these effects are all serfous for their effect is to increase the gelvenic attack of $2-5$ aluminum corroding in preference to $72-5$ aluminum when the solution potential of the $2-5$ aluminum is less"* tharethat of the 72-5".

of course, this remark is not true of 1 tems 1 and 3 . The vord "change" $1 \mathrm{mplies}$ nelther direction nor magnitude. If the IIIm mentioned 10 the third effect actually forms, and if the film is incomplete, the current density is injoased at the anode, but the total current 18 unaffectod, 1.0., the galvanfc attack : I localized, but not increased. If the film is not perforated, then the only effect 18 to decrease the galvanic current. Since pitting is not observed in the presence of $2 \mathrm{ppm} s 0 d 1 \mathrm{um}$ dichromate, the latter effect must prodominate.

Clearly, Item 2 is 1rrelevant, since in waters of interest, whero the 1on concentration lies in the range of 75 to $100 \mathrm{ppm}$, the frect on the conductivity of adding $2 \mathrm{ppm} \mathrm{Na} 2 \mathrm{Cr}_{2} \mathrm{O}$ w wll be insignificant. (In tho experimental work reported in ref. 16, the concentration of $\mathrm{SO}_{4}=$ ranged from 80 to $120 \mathrm{ppm}$, depending on the degreo of $\mathrm{pt}$ adfustment with $\mathrm{H}_{2} \mathrm{SO}_{4}$. The conductivity of the solution varied from 2 to $4 \times 10^{-14}$ mhos.)

No work was done in the electrochemical studies to 1dentify the specific polarization effects whlch were acting to produce the very low corrosion currents observod. Any depolarization elther did not occur or was alight relative to the obvious polarization actually observed, as indicated by the rery small currents. Therefore, the only Important effects were $1,3,5$, and 6 , the observed decrease in the potential across the $72-5 / 2-5$ cell reducing the tendency for corrosion and the dillinution in current representing a reduction in actual corrosion. Consequently, under the conditions of these tests ***, $72-S$ aluninum has little value as protective anode for $2-5$, but all galvante corrosion due to aluminum couples 1s materlally roduced because of the polarization. Th18 11 st 18 quoted exactly from rer. 16. Rer. 4, which claimed to be quoting
rer. 16, reworted 1tem 3 as follows: "May form a $11 \mathrm{~lm}$ on the anode which w1l decrease the anodic area, which would result in local pittingn. Nel ther reference makes clear that such local attack would be assoclated only with laok of intogrity of suoh film if it forms.

* By 108818 presumably meant mor8 electronegative, 1.0., more anodic.

onn" Sisrod boakers, with almulatod Hansord wator.
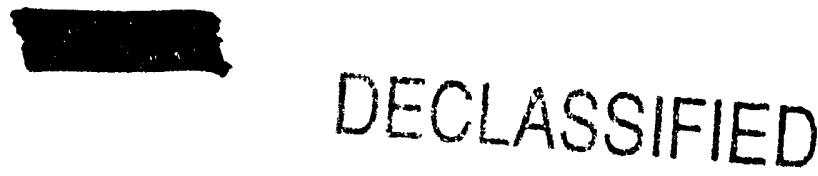


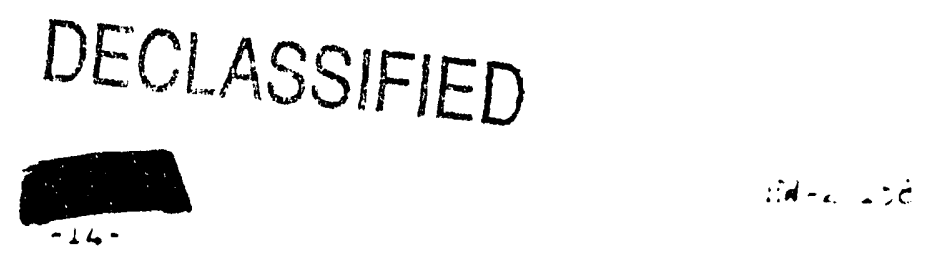

-

For all these reasons, the conclusions reached in ref. 4 relatire to galvanic effects are Incorrect and should be reversed. For examples "The result of this offect in that, in all cases where 2-s aluul mum 18 corroding to $72-3$, the use of $2 \mathrm{ppm}$ oodium dichromate will increase the rato of attack" should read ". . . . decrease the rato of attack".

OFT SITE MOCR-UP STUDIES

is a matter of lact, the laporatory 1mvestigation of the galranic effects in the 2-S/ 72-S system had very 11ttl. applicat1on to the Hasford p1les. That such was the r.ase was woll brought out in a concurrent ser1es of gxpprisents at Ch1cago in which an attempt was made to include the velocity erfect(17). In this study couples wore exposed in a Nlow systom at $15 \mathrm{ft} . / \mathrm{sec}$., the solutions and inst fuments being those used in the beaker study. The concluslons of lnterest weres (27)

1. When couples of otalnlose oteol and 2-5 alumbim vero lested in the beaker sot-upe uoing almulated river vator, pitting of the aluminum usually occurred withlin two to throe daje, worvas in the nowling systems there was no orldence of poting after seren or elght days.

2. It appears that the Now and static tost dats can be correlatod only to a IInited extent. In solutions of simulated river vater containIng $10 \mathrm{ppm} \mathrm{S}_{1} \mathrm{O}_{2}, 2 \mathrm{ppm} \mathrm{AaCr}_{2} \mathrm{O}_{7} \cdot 2 \mathrm{H}_{2} \mathrm{O}, \mathrm{pH} 7.5$, tomperatures of $7 \mathrm{O}$ and $x \mathrm{C}$, in Geasing the $\mathrm{H}_{2} \mathrm{O}_{2}$ concentration from $5 \times 10^{-5}$ to $10^{-2} \mathrm{~N}$ had 7ery 11ttie effoct on the olngle potontials of 72-5 and 2-S aluninum in the nowng oystom, and orer this range 72-S was allghtly anodic to 2-S alumime. In the beaker toste, increasing the $\mathrm{H}_{2} \mathrm{O}_{2}$ concentration abore $10^{-4}$ II caused the $72-3$ to becomo cathod1c to $2-5$.

The galvanic currento dereloped botwoen the 72-S and 2-S aluminum also showed that the $72-S$ alum num vas anod1c, wheh would indicato that the clad $72-S$ would tond to provent pits from pontrating into the $2-3$ coren.

In none of the reports discussed above 1s there a consideration of the probably declsive influence of the tomperature gradiant across the vater anmulus on the direction of galranic current now in procels tubes. Bocause of the low conductifity of process water, it 1s unlikely that the cell made up of the couplo botimen olugs and tube wall is responsible for the major corrusion process. However much th1s particular galvanic corrosion occurs, it is quite clear that $2 \mathrm{ppm}$ sodilum dichromato would tend to reduce 1 ts extent and to assist the temperature of fact to maintain the highly desirable polarity oltuation in wich the slugs aro anodic"."

- (1.0, the decreased protection of the 2-S due to the decrease in potential difference and corrosing eirrent 1.2 the 2-S/72-S cell.)

* Ref. 4 glizes the 1mpression that such a polarity 1s highly undesirablo, which amounts to a preference for tube leaks instead of ruptured slugs, or at least a periodic complete tube replacement program, a elfficuitly tonablo position. The primary function of the sacrific1ed $72-5$ layer on the tube wall ls not to protect the slugs, At to protact the tube; and, in order to porform this function, the $72-S$ must bo anodic relativa to the $2-5$ tub wall. There is cortainly not snough 72-S alyminum present to rendor protection to the eluge for any extenflat parict. Cloarly then, if tho ol adsing layar ta oorrualing to tho eluge, tho not of fect 10 lo dimins the protostion afforded the tube in favor of providing a more or less uselose protection to olugs which, in any event, have a relatively short ilfe.

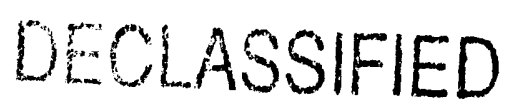




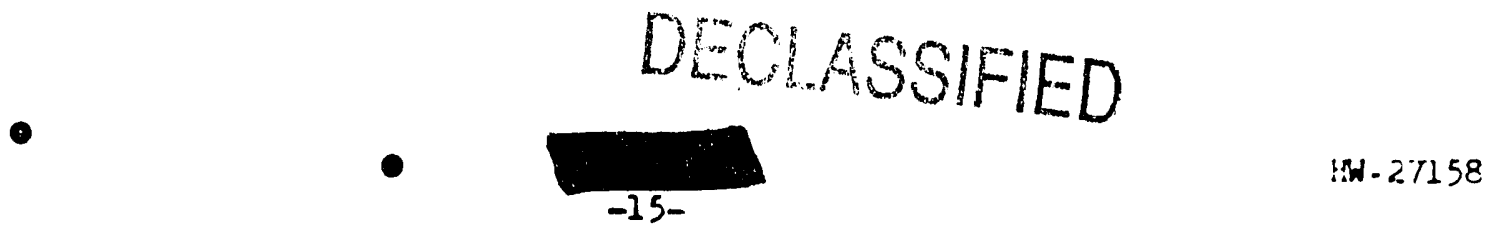

One other corrosign research, carrled on at Chlcago, was a pilot plant profoct, on a somewhat more modest scale than CMa $(18,19)$. Rather short prototype tubes and prototype fittings wero exposed to simulated Columbla River vater under conditions of internal heating and actual proposed velocities. Principal conclusions did not differ matorlally from those discussed abovs, 1.0. below $95 \mathrm{C}$ untform corrosion 1s very small up to $\mathrm{pH} 7.0$, pitting froquence is minimel In the rogion $\mathrm{pH} 7.0$ to 8.0 and Increases with increasing rapldity on the ac1d side. Sodium dichromato at 2 ppm gave some reduction in overall corrosion in the noighborhood of $\mathrm{pH} 8.0$ and maximum securlty from pitting.

\section{CORROSION AND RADIATION}

In all of the Invostigations discussed sbove, the offect of $\mathrm{B}_{2} \mathrm{O}_{2}$ on aluminum corrosion was studied in an attompto simulato the orfoct of radiation. The only cluar result, considoring all of the various datn, 1s that in the concentration range of interest, $10^{-4}$ to $10^{-5} \mathrm{~N}$, peroxlde has no deltorlous orfect. Some indications vere obtalned that $\mathrm{H}_{2} \mathrm{O}_{2}$ could act as a general corrosion Inhibltor or as a pitting corrosion 1 nhibitor or both. Although the presence of $\mathrm{H}_{2} \mathrm{O}_{2}$ simulatod one condition which 1t was expected wou:." be produced by radiation, it was not known to what extent corrosion would be affectod by the in situ formation of peroxide or by associated radiation efrects.

Aside from the indirect offect op the corroding medium it was expected that the main action of pile radiation would consist in a considerablo lovering of the acilvation energies of reactions occurring at the solution motal intorface (20). In the cnse of metals which tond to form f1lms, the reoult would be an accelerated inftial corrosion, due to this jepolarization, until a strongly adheront oxide cont had been ostablished. It was thought that this is $\mathrm{m}$ ohould have high intogrity and good protective qualities, because of 1 to acceleratod in sity formation.

A number of experiments were carrled out using hlgh intensity spocific soleces, such as cyclotrons, and the relotively wak sources provided by the plles in operation prior to the Hanford piles $(21,22,23)$. In goneral, these tosts gave a good simulation of pile conditions, yth the major exception of a high noutron flux. (Any conjolnt action due to the colicidence of high intensity beta, gama am neutron radiations, was not possible efther). In all such investigations, the same conclusion was apparent, namely, that the effect of radiation on eluminum corrosion was beneflcial or nll, 1.0., corrosior rates, as measured by welght losses, tonded to be lover in the roliation fleld. Ono vory interesting agpect was obserred in an electrical study of the 2-S/72-S couple in the CIInton P1le (22) It was show that the pile radiation made the 72-S more protsctive, (the current and potential increased several fold) and greatly increased the galvanlc corrosion due to the cell. The addition of $2 \mathrm{ppm}$ dichromate more than of fset the radiation effect as shown in Plgure 6.

\section{CONCLUSIONS FROM EARLY CORROSION INVESTIGATIONS}

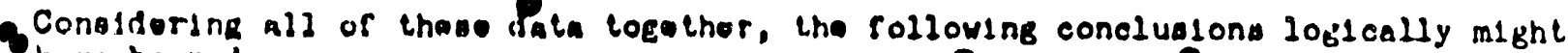
have boon drawn:

1. Corrosion predictions from out-of-pllg experimente probably would not ho Broatly in error for actual pile operailon.

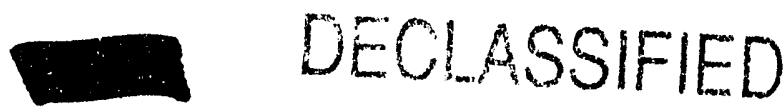




\section{DECLASSIFIED}

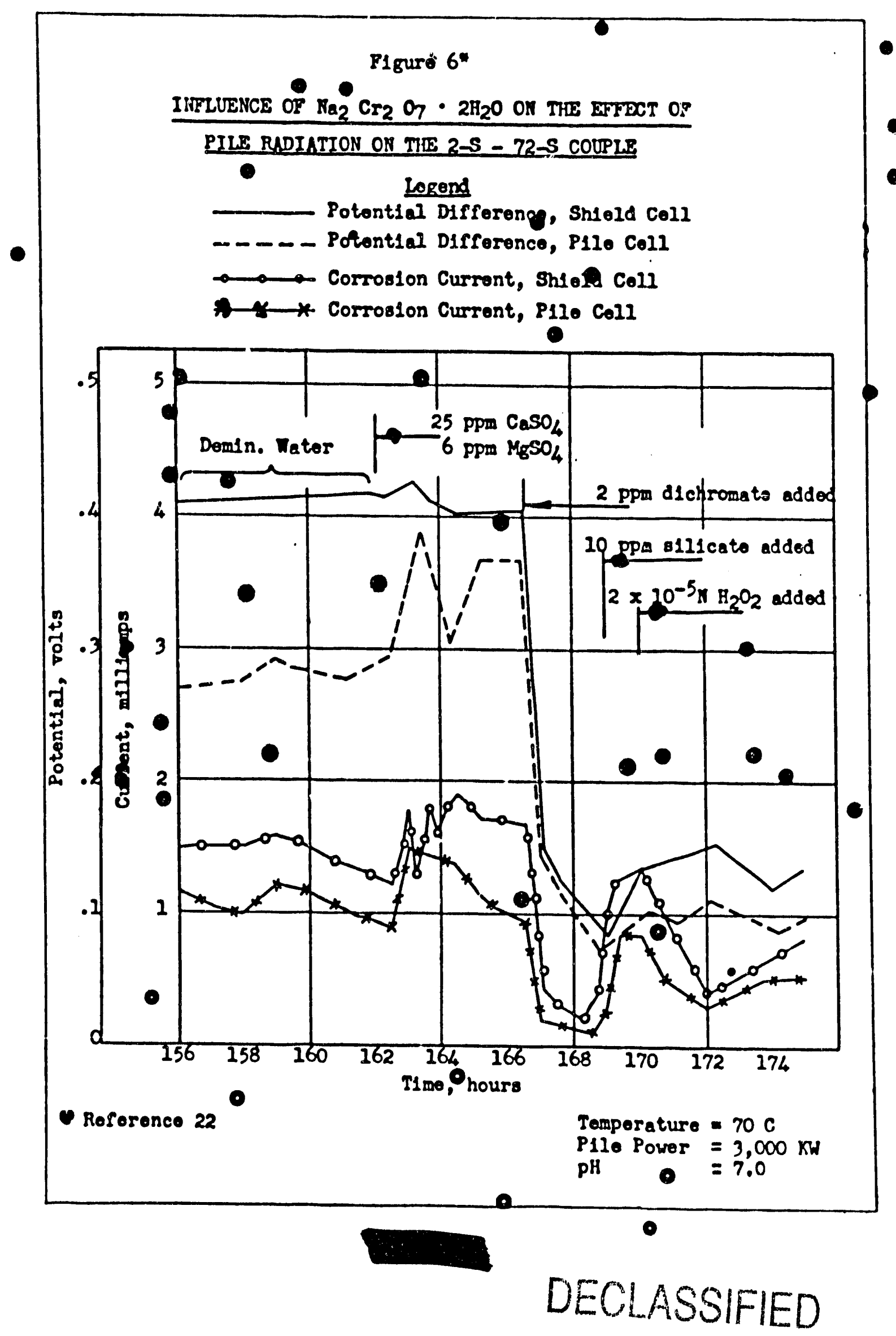




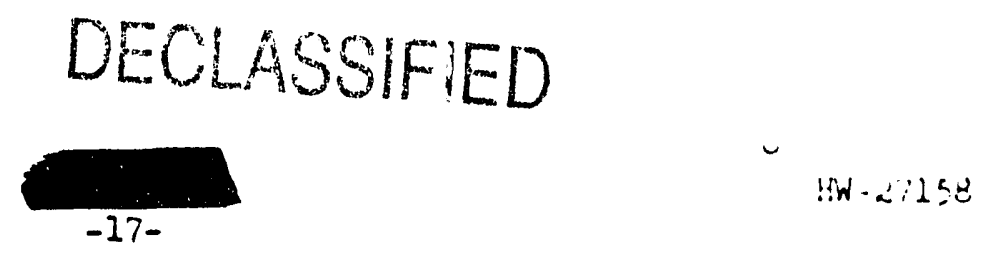

2. Hanford water undor practical operating conditions would have somewhat greater corrosive tendencles than higher purify waters.

3. For securlty from pitting, the minimum $\mathrm{pH}$ which could be considered wouid be in the range 6.5 to 7.5 , possibly on the low side.

4. The unf form penetration rate would reach an excesgive level in the range pH 7.7 to 8.0 .

5. 2 ppm sodium dichromate would give greatiy enhanced securlty from pitting throughout the $\mathrm{pH}$ ranged 6.5 to 8.0 .

6. In the presence of 2 ppm sodiun dichromate, uniform penetration would not be excessive below $\mathrm{pH} 8.0$.

7. In the prosence of $2 \mathrm{ppm}$ sodium dichromate, or ahove a pH somewhere in the range 7.0 to 7.5 , the use of $72-5$ olad tubes would have questionable value, however, with dichromate, l1ttle danger, el ther.

8. In the presence of sodium dichromato, galvante corrosion in general wolld be mintmired.

9. While sodium dichromate at a concentration of $2 \mathrm{ppm}$ is satisfactory, some other concentration, probably in the range 0.5 to $5.0 \mathrm{ppm}$, might be better.

\section{RADIATION AND SODIUM DICHROMATE} Towards the end of March, 1944, the status of the CNa study could be aumarl zed as
follow:

"It was found at Cha that about $20 \mathrm{ppm} \mathrm{SIO}_{2}$ dissolved in water as sodium silicate is sufficient to fuhibit ohe formation of a film deposit at $\mathrm{pH}$ 6.5. This undemineralized water 18, however, not ideal for passage through eluminum tubes containing aluminum-costed slugs. Pitting-corrosion and 1mpingement-erosion are observed. These effects are in turn Inhibited by the addition of $2 \mathrm{ppm}$ of $\mathrm{Na}_{2} \mathrm{Cr}_{2} \mathrm{O}_{7} \cdot 2 \mathrm{H}_{2} \mathrm{O}$. The problem of handiling this water was consequently consldered woli in hand until Higner pointed out that the reduction of dichromate under 1rradiation had al ready been roported (CN-467 and Frlcke, J. Am. Chem. Soc. 52, 2358 (1933))".

Starting in May of $15 \%$, CND ran a series of otudies on the film forming tendencies of chromic lons $(25)$. Shortly, it was discovered that $C r^{\text {tot }}$ at a concentration of $0.1 \mathrm{ppm}$ or lower produced a heary pressure drop film at a very rapid rate. The most serlous aspect, hovever, was that the : ? Im could not bo removed readily by purging with solids, the only effective purge for $\mathrm{Cr}_{2} \mathrm{O}_{3}$ f1lms involving the use of high concentrations of $\mathrm{H}_{2} \mathrm{O}_{2}$, a dubiously practical materlal. It was finally concluded that the moximum tolerable concentration of $\mathrm{Cr}^{+}$would be in the nelghborhood of 0.02 $\mathrm{ppm}(26)$. While the extrapolation of this result to the ples is somewhat more certain than the resuio on $\mathrm{Fe}_{2} \mathrm{O}_{3}-\mathrm{Al}_{2} \mathrm{O}_{3}$ films, there is a possibility that the figure should be revlsed el ther up or down.

Thereafter a number of experiments, wero yndertaken to assess the extent of radiation induced reduction to be efpected $(24,27,28,29)$, and the influence of various conditions. The following polnts were olucidatod: 0

1. In one passage thgough the pile the equilibriums

$$
\mathrm{Crg}_{4}=4 \mathrm{H}_{2} \mathrm{O}+30^{-}=\mathrm{Cr}+1+8 \mathrm{OK}
$$

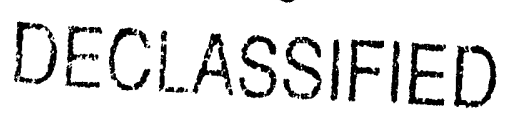




\section{DECLASSIFIED \\ $\odot$}

$\odot$

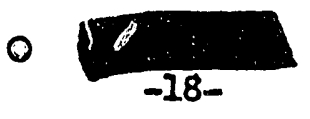

HW -27258

will reach a stoady stato. Onder any water quality contemplatied for p1lo use, the value of the ratio $\left(\mathrm{CrO}_{4}=/ \mathrm{Cr}^{+t+}\right)$ equilibrium will be finite.

2. The magnitude of $\left(\mathrm{CrO}_{4}=/ \mathrm{Cr}^{+t+}\right)_{\text {eq. }}$ 1ncreases w1 th $\mathrm{pH}$, w1 th temperature, w1 th silica concentration, and, up to a point, with oxygen concentration.

3. The magnitude of $\left(\mathrm{CrO}_{4}=/ \mathrm{Cr}^{++t}\right)$ eq. decreases with $\mathrm{CO}_{3}=$ concentration, with the amount of $\mathrm{H}_{2} \mathrm{O}_{2}$ produced, and pertiapa with the prosence of minor Impurities.

4. The magnt tude of $\left(\mathrm{CrO}_{4}=/ \mathrm{Cr}^{++H}\right)$ oq. Increases with radiation Intengity.

Because of 1 ts unexpectedness, considerable effort was spent in f1umly establishing this last relationship.

The earliest conclusion reached was that no appreciable reduction would be expected in Henford water at $\mathrm{pH} 7.5(24)$. Tht early experiments in the CP-3 $P_{110}(27)$. It was felt that, due to the uncertainty in extrapolating to the Hanford piles and to a discouraging experlment with real Hanford water, "a pll of 7.8 should be safe as far as ghrpmate reduction 1 s concerned, and a $\mathrm{pH}$ of 7.5 or 1088 may woll prove practicablen(27). Later vark however, was more encouraging, further experlments on real hanford vater profing more satisfactory than those oncsimulated water (28) and the earlier sample of Hanford water. Finally, on the basis of the temperature and intensfty effects:(29)

It appears that a pH of $7.5 \mathrm{will}$ certalnly be safe for $\mathrm{W}$ operation as far as formation of trivalent chromium is concerned. It is quite pobable, but not absolutely certaln, that a $\mathrm{pH}$ of 7.0 or even lower may be used without exceeding the prescribed tolerance level of fresh trivalent ciscomiun in the $W$ cooling writer".

Apparently beckuse of susplelons of the intensity effect and to allow for uncertainties in extrapolation, it was decided to operate abovo $\mathrm{pH} 7.5$, if this proved otherwse feasible. Ample experience, of course, has shown that operation above $\mathrm{pH}$ 7.5 is safe from the point of Flow of dichromate reduction, but nothing appears to have been done to ascertain the sofe minimum pH. Presently, hovever, experiments are bolng conducted along this 11 no $(56)$. (It should bo pointed out that this minimum would drop approximately $0.15 \mathrm{pHQunit}$ between sumer and winter, corresponding to the $15 \mathrm{C}$ decroase in river water temperature. The position of this $\mathrm{pH}$ minimum would perhaps show a seasonal varlation due to changing river waterolmpurity content.)

Actually the extrapolation to the higher intensities expected at Hanford was rather short, as can be on in Plgure 7. Probably the main reason for not wishing to extrapolate the 1ntensity effect was 1ts rather unbellevable nature. Cirariy as the intensity becomes smaller and smaller, the amount of chromate reduction cannot increase wh thout lintt (in terms of Figure 7, the curves shown there must somewhere bend cback to the $X$-axfo, ultimately becoming asymptotic as the reciprocal of the intensity increases without 11mot.)

The fact that the ratio ( $\left.\mathrm{CrO}_{4}=/ \mathrm{Cr}^{+4+}\right)$ eq. Incroases with intensity may be justiffed theoret1cally. The reduction of chromato is probably a socondary effect, arlsing from the reaotion w1 th $\mathrm{H}_{2} \mathrm{O}_{2}$ or more probably, OH radical, whleh 10 the primary product of radialion. Sinco tho uquilibrlum concontration of $\mathrm{H}_{2} \mathrm{O}_{2}$ can be expoctod. to increase with intensity, ami since the extent of dichromate rodyction 1s observed to be an inverse function of the equilibrium concentgation of $\mathrm{H}_{2} \mathrm{O}_{2}$, the observed
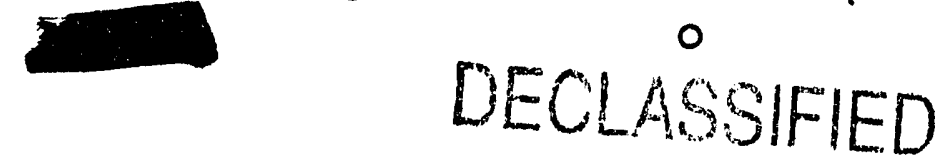


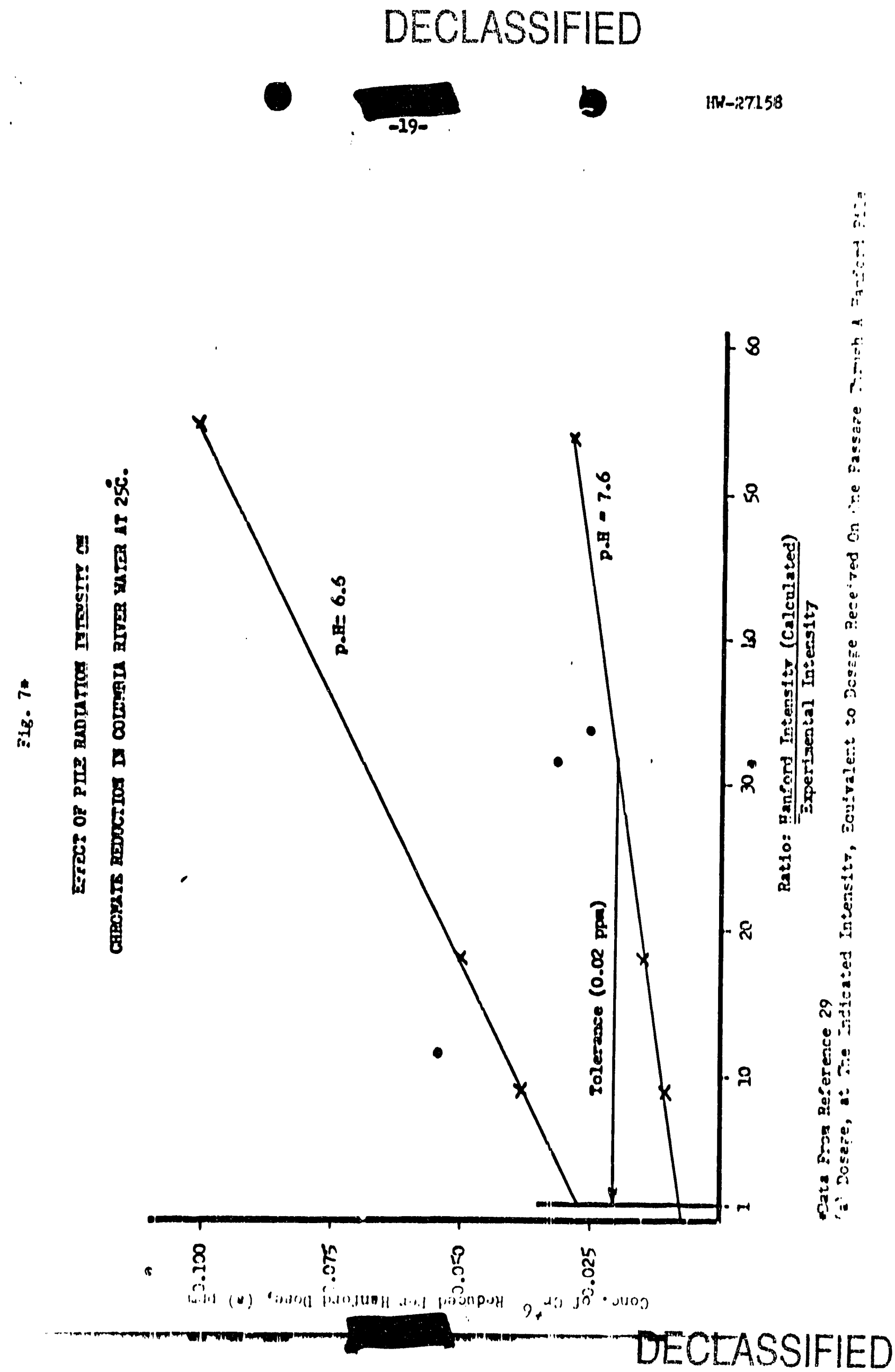




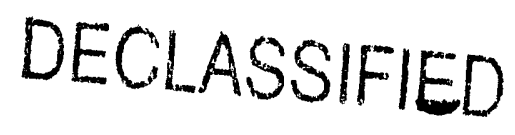

$-20-$

HW-27158

1ncrease in the ratio $\left(\mathrm{CrO}_{4}=/ \mathrm{Cr}^{++\infty}\right)$ oq. 1s not unreasonable.

SUMART

If, for safe operation of the plles, it 10 assumed thats

1. It is essential to provide maximum securlty against pitting typo corrosion,

2. It is highly desirablo to have a low, unfform corrosion rate, and

3. It is essentlal that Fllm formation be controllable, and hlghly desirablo that it be prevented altogether,

then certaln conclusions aro inescapablo.

1. The oridence from the pro-otart-up 11terature 1s orerwhelmingly in faror of the use of sodiun dichromato at a concentration of $2 \mathrm{ppm}$, though the possibility of some other concentration or even some other inhibitor 18 not procluded.

2. Any pH in the range 7.5 to 7.818 probably safo. From the corrosion point of vier, ang pH in the range 6.5 to 7.5 vould be more desirablo and is not precluded by other pile operation considerations. The safo minimum woild be determined elther by the pltting probability or by the reduction of dichromate. The protection rendered by dichromato against pitting probably begins to fall as the $\mathrm{ph}$ is reduced below value near 6.5 , there 18 an excellent chance that the roduction of diciromato 18 not problbitivo at least at pH 7.0 and possibly below.

3. From the polnt of Flew of the 11terature discused above, operation should have begun, as 1t d1d, at ph 7.5 - 7.8 and with the addition of $2 \mathrm{ppm}$ sodium dichromate. The next logleal stop would have been in-p1lo oxperlmentation directed to lowerlng the $\mathrm{pH}$, with the hope that operation at $\mathrm{pH} 7.0$ would bo feasiblo, wh1lo still loarling a margin of orror of fow tenths of a pll unt.

\section{PAPT II}

\section{DICHROMATE ELIMINATIOA}

Because of the unfque stringency of process water speciflcations, the orlginal water troatment method was sabjeot to gopsiderable crltical revlew, both from the standpoint of cost and of operability (2). In the course of this program, number of 1mprovements and simplifications of the CNA process were effegfed by the Power D171s10a culminating in the olimination of sodium silicato additions $(30)$. An obvious further step was the ro-evalustion of the need for sodium dichromato. Because of a lack of sultablo laboratory facllities, information from unclassiflod sources, which had only a limfted relevance, was cited in an effort to show that dichromato should be oliminated, al though no complete tudy of the early pruject literaturo appears to havo been mado.

The corrosion 11terature makes froquent reforence to the use of chromato 1phipitors in a varioty of service cond1t1ors. As typified by the "Corroalon Handbookn, (I3) such situations inrolvs the nos of steol or aluminum in rather corrosive environments. The "Corrosion handbook", whon montions in partl oules usen of shromate or diohromate, alway doos no with roferenoe to highly apoolflo asotom. Onfortunately, thio polint has somotimos boon orerdooked. Raforanos 4, for examplo, otates!
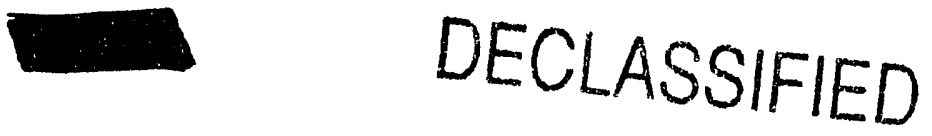


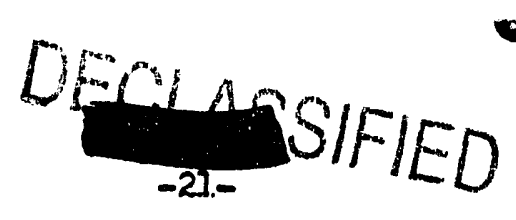

HW-27158

"G. G. Fldredge and J. C. Warner in the 'Corrosion Handbook' stato on page 913 that, in rocirculation oystoms, . from 500 to 1,000 ppm dichromate are necessary".

On pago 913 of the "Corrosion Handbook" the only wetal mentloned is steel, and the recommendation of the above amounts 1s. only for closed, recirculating oystems where the Inhibltor depletion may bo high. For reclreulating systems wlth $1088 \theta$ and makeup, as little as $100 \mathrm{ppm}$ can be used, with the possible exception of a short inftial period. Further points brought out on page 913 are that: 1. The anount of Inhibitor needed decreases when contact with open air is
maintained.

2. The amount of inhtbitor needed Increases with a decrease in the "degreen of agitation.

3. The amount of Inhibitor Increases with the salinsty of the water.

In the case of aluminum, handling recirculating water, 1,000 ppm are recommended on page 914; but with reference to brines:

"The Aluminum Research Laboratorles recommends one percent as much sodlun dichromato as there is chlorlde lon prosentn.

In such reolrculating oystems the problem is not provonting a low overall concentratiun, but in preventing a very low concentration at some specific sito, due to local depletion through use. In the Hanford reactors, where turbulence la very high, and overall depletion impossible, the only requirement is that the bulk water concentration exceed the maximum locel instentaneous requilrements, which, in this relatively pure water, is probably very low. The older literature, of course, is very clear on the dangers of anodic inhibitors at insufficlent concentrations $3 i$ ). If insufficient inhibitor 18 present, the area of attack is diminishod moro rapidiy than the total attack, leading to a high rate at a small site, 1.0., pitting.

In 1951 , several offsito consultations $(6,32,33,34)$ led to conclusions substantially similar to those drawn from the "Corrosion Handbook"; that $2 \mathrm{ppm}$ was dolng no good and possibly some harm, on the grounds that this concentration was too small. Alcoa, for example, did not approve of chromate inhibition, suggesting sodium nitrate instead; but felt that if used, the concentration of sodium dichromate should be at least

\section{JUSTIFICATION OF THE DICHROMATE EITMINATION TEST}

It should be recalled that, in 1951, slug corrosion rates were rising drastically as power levels and temperatures were increased". Simultaneously, a slug rupture problem

- The Intermingled iffects of simultanoously changlng several varlables produces subtlo pltfalle. Roforonoe 4 trled to show that the elimination of olilcato addstions in 1949 lod to an incroase in corrosion rates. Pygure 2 in that document is a plot of corrosion rate vorsu timo, and 1 s ohow that in 1949 the rato moro than doubled aftor oll1onto olimination. Unfortunately, it 10 not pofnted out that the 1949 pointo are from the wlovated tomperature produotion test $(3 \xi)$ and that the tube outiot temperatures for these points vero about $25 \mathrm{C}$ higher than for tho earlier dat.

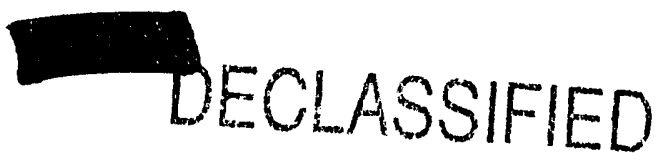




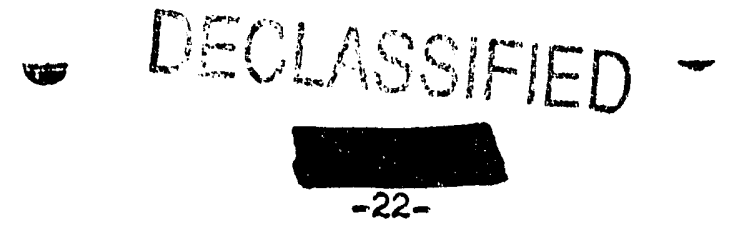

HW-27158

arose, and varlous efforts were made to justify the elimination of dichromate on the grounds that it was responsible for most corrosion problems. Since there were nelther laboratory nor p1le data of recent Fintage to support or refute this notion, the case had to be made on grounds sygh as those discussed above. Thus, J. E. Draley, ANL Corrosion Chemist comented $(6)$,

"It is quilto possiblo that no improvement leading to higier corrosion resistance of the slugs or tubes would be necessary if the water treatment were changed to give a less corrosive medium. There 18 no apparent reason for adding the dichromate and there are several indications that it is harmful. With dichromate absent, the only known reason for operating at a potentially dangerous $\mathrm{pH}$ corrosion-wise, is that it is belleved that a slightly higher rate of I1Im formation would be observed at lower $\mathrm{pH}^{\mathrm{m}}$.

Even though the slug rupture problem had been practically non-existent before 1951, 1.e., for over five years, attempts wero made (4) to explatn the h1gh frequency of ruptures, which come with increased power levels, as being due tc p1tting causpd by insufficient inhibitor. Th1s is inconsistent with the well known fact 15,36$)$ that pitting tendencles decline with increasing temperaturo. Another approadi $(4,12,10)$ to the same problem was the following argument; (12)
"It can be shown that the normal polarity relationshyps between the two metels (2-S and 72-5 aluminum) may be reversed by tho heating of tire alloy with the lower potential; the polarity relationships may also bo reversed by adding sodium chromate to the water. Since tine slug jackets are hotter than the tube wall, it would be expected that the slug jacket would corrode sacrificlally, and the presence of oodium dishromate may accelerate this corrosion raten.

Here the conclusions of reference 16 are belng partially drawn upon. While the predence of dichromate may indeed reverse the normal polarity, it does this by "leveling" the differences botween the separate anodic potentials to the polnt where minor fluctuations determine the actual polar1ty. Further, the temperature coeff1cients are reduced, so that dichromate, as polnted out eariler, would tend to offset greatly the magnitude of this thermogalvanis effect.

Another approach is to consider that $2 \mathrm{ppm}$ sodium dichromate is grossly inadequate for anodic inhibition, so that the only effect would be cathodic depolarization. On the basis of reference 16, such an effect would be very unlikely; though, if it occurred, the result would be an increased unfform corrosion rate. This effect is presumably what Draley had in mirl, though his major criticism was the high $\mathrm{pH}$ occasioned by the use of dichromate.

Probably the most aerlous charges loveled againgt the use of dichromate were in connection with the problem of front tube corrosion. There are two important aspects of this problem. The f1rat was the pitting of Van stone flanges, due to the couplo between stainless ateol noziles and tubo willo. ChX had found that dichromato
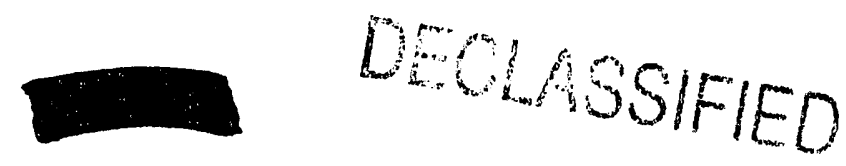
prevented this type of attack", but apjarently their runs were not of sufficlent length to show that dichromato only decreaser the probabllity of this attack, but did not prevent 1t. Th1s phase of the front tube program was solved by replacement of stalnless stoel with galvanized or aluminum nozzles.

The second espect of the problem did rot appear unitil the elimination of the front dumy pattern. It was then found that a pitting attack developed in the low velocity sections at the front of the tubes, charanterized by the growth of mounds, or harnacles, of whits corrosion product over the pits. This attack was not partigulariy threatening since 1t did not 10rolve more than a fraction of the tube surface 37 and since the 72-S cladding was giring complete protection to the $2-5$ tube wall $(38)$, as predicted by reference 17. Th1s, howerer, constituted a pltting attack which sodium dichromate was not preventing, and so the whole ablilty of dichromato to prevent pitting was rightly questioned. Since the presence of lead had been detected in pressure drop films, it was further conjecturij that particles of the insolublo laad chromate pere settling in the low velocity sections and possibly causing this barnecle attack $(10)$.

\section{THE DICHROMATE ELTMINATION TEST}

The cost of adding sodium dichromate was about $\$ 300,000$ per annum, (II) and enough considerations, as citlined above, having been advanced to raise seriuus questions regarding the desirablity of 1 ts use, a production test ras infliated to study the feasibility of stopping dichromato addition. Thls tost (2i) wes run using the recircuiation equipment at $\mathrm{H}$ PIle to pass filtered water without dichromato through two reactor tubes, one of which was nowly installed for the test. The charge consisted of 58 regular metal slugs and six dummies. Two normal tubes, one of which was new, wero similarly charged and operated on process wator as controls. The actual test ran for f1re months, and the slugs were carried to 65 percent of normal exposure. At the conclusion of the experiment, it was found that there was ilttlo or no evidence of pitting in ol ther the tost or control systems. (Some front tube pitting was observed in both old tubes, but this was probably not incurred during the test.) On the other hand, above $35 \mathrm{C}$, olug corrosion rates for the dichromate-free oystem were found to be 40 to 50 percent lower than in the regular process water tubes. (The corrosion data for the control tubes were in good agreement with the values predicted from corrosion rato monltoring.) Since every second slug was weighed, these data correspond to that which would be obtalned from one full tube. Largely on the basis of the slug corrosion data obtained, dichromate was oliminated at all areas(39). (At $F$ Area, and later at $D$, where the chango frnm Ferrifloc to alum coagulation resulted in a 50 percent decrease in slug corrosion rates, it was assumed that a further reduction would occur when dichromate was removed.)

- CMX FInal Roport sayB:

"A major adrantage of using this inhibitor 1108 in the nearly completen absence of pitting type of corrosion when 1t 18 used under conditions whlch normally would cause severe pltting, as for examplo when alum num 1s in contact with stainloss stosl, particularly at higher $\mathrm{pH}$ $(7.5-8.0) \%$.

Thio olacomont, taken alono, appoare to have given tho Improselon that tho maln roason for using godfum dichrometo was to provont corrosion due to the stainloss otoul alumnum couplo (12). There are, howepor, a number of other remarke in reforence 3 relative to the ablisty of dichromate to prevent pitting in general.

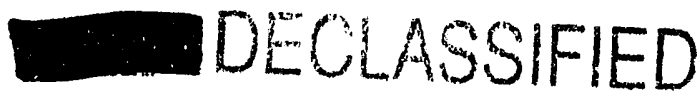


In eraluating the results of the dichromate elimination test, there are tro important polnts which must be coneldered.

1. During the course of the test, 22 hours of the 4418 hours of total operating time wore spent on process water with dichromate, since the test of stem was tripped to process water during the bl-wookly pile purges. It nas been establishod by Nlcoa that the offects of adding or removing Inhibitor may persist for some time, oven running into months, after the actual change is mode(34). This 1steriftent addition of dlohromato courd weil have had a profound influence on the occurrence of pltting, though it is less obolous that the corrosion rate would be affected.

2. Since the conclusions of the test were effectively based on one tube, - IIminating dichromato throughout the piant amounted to extrapolatias from one tube to over 10,000 .

\section{LOW PH EXPERTMENTS}

Concurrently with the dichromate olimination tost, a serles of experiments vere run in the new water qualf ty Flow laboratory to study the effects of lowering the $p$ H of dichromate-fres water (36). In these experiments, flitered water at ph's 6.2, 6.7, 7.2 , and 7.7 was passed through mock-up tubes at temperatures of $65 \mathrm{C}$ and $95 \mathrm{C}$ after preheating in a heat exchanger". The results of this work egreed very well with what would have been predicted from the CNS date and the Chlcago Iaboratory work. is the pH was docreased, the corrosion rate fell off rapldily to a very low value at pH 6.2 with no $81 \mathrm{gn}$ of a mintmum at $95 \mathrm{C}$, and with a broad mintmum in $65 \mathrm{C}$ water, the rates for $7.2,6 \mathrm{a}$, and 6.2 being substentially the same. The rirulent pltting terdencies of Columbla River water found by Cha wore also very apperent, showing ail predicted tendencles. The percentage of pltting, dangerous evan it pH 7.2, incroased fairly rapldiy with decreasing $\mathrm{pH}$, and decreased by about 50 percent on increasing the temporature from $65 \mathrm{C}$ to $95 \mathrm{C}$. No actual p1tting was observed at $\mathrm{pH} 7.2$ at $95 \mathrm{C}$ or at pH 7.7 at $65 \mathrm{C}$ or $95 \mathrm{C}$ after 90 degs of operation, but an extrapolation of the trends would 1ndicate that even at $\mathrm{pH} 7.7$, at least at $65 \mathrm{C}$, there 18 a $8 \mathrm{mall}$, but real, probablilty of pitting after moro lengthy exposures.

In the face of the experiments discussed above, it would appear that the following conclusions can be draws:

1. Though it 1 possible that, because of the heat exchanger effect, the $\mathrm{pH}$ tests gave an overly pessimistic view, removing the sodium dichromats from process water would reduce securlty from pitting oven if no change in the pH was mado.

* Numerous experiments in the last year have given indications that it can be dangerous to draw absolute conclusions about the corrosivity of water that has ben heated in a heat exchanger. Such water occasionally has 1ts turbidity 1ncreased by the introduction of scalo, producing a higher rato of erosion-corrosion. Wate at some intermodiate temperature which huo boon produced by mixing cold and hot wator 10 Dowhat difforont than water hoalod diroctly to tho intormodiato lomporaturo. The concontrations of dissolved gases tmy be sorlously disturbed in particular the $\mathrm{pH}$ may Increase due to the expulsion of $\mathrm{CO}_{2}$. A generel discussion of the relation betweon flow laboratory and In-pile results is given in reference 55.
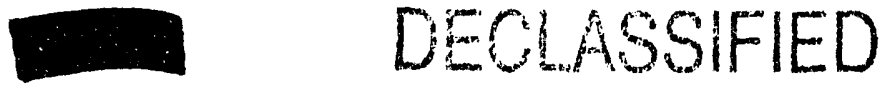

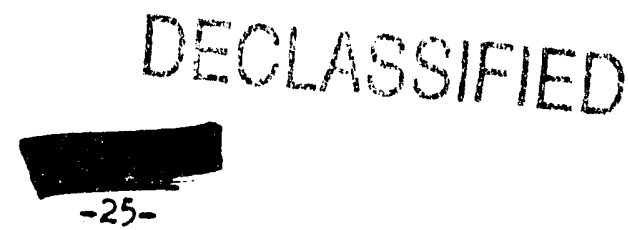

HW-27158

2. In the absence of dichromate, no change to lower pH's could be contemplatal without extensive corroborating experimental data.

3. Though the results of the dichromate elimination test are not unequivocal, It was probable that remoring dichromate would lower the corrosion rate.

4. Since the over-riding corrosion consideration is the prevention of pitting, 1t would have been desirable to have more conclusive data to justify the complete eimination of dichromate from process water.

\section{PART III}

THE ERTECTS OF DICHROMATE ELTMINATION

The vater plants have now operated for over ten montins whthout dichromate, and laboratory vork dealing with several aspects of the effects of dichromate has been greatly expands; much new information has thus become avallable. In interpreting the behavior of the plles, it must be remembered that, in the perlod immediately following the elimisation of dichromate, the film of adsorbed chromate lons, previously built up, was slouly beling removed. Consequently, ang inhibiting action of dichromate might be retalied in part for some time, and there would be a short perlod during which the dangerans effects of having insurficlent inhibitor might be expectod.

\section{FRONT TUBE CORRCSION}

Some moths after the elimination of dichromate, it became apparent that the front tube corrosion $p$ roplem was approaching an acuto stage. Routine Inspections, instituted

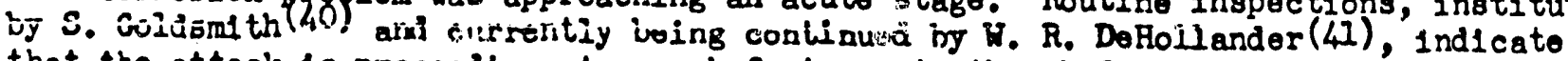
that the attack is procoeding at a much fastor rato than before dichromato was taken out. Dofortunately no information is araliable on the stato of front tube attack at the t1=e of dichromato olimination, 80 a detalled comparison is not possible. In fact, the only provious study of this problem was an examination of 123 tubes at $B$ P1I0, 26 at $F, 30$ at $B$ and 50 at $D(37)$. At the time of this inspection, m1d-1950, the attack was negilgible compared to what $\therefore$ is now; the worst tubes in the 7959 surver woult all fell wil within the lowest rar.ge on the scalo used by Dellollander 731 , 1.0., where the number of barnacles is countable during a quick look. The consensus seems to bo fafrly definst that the attack has been proceeding at a much faster rato in the last ton months than was ever the case before the allmination of dichromate $(40,41,42,43)$. It is certalnly trup that the corrosion occurring on the cap supported shielding pleces is much worse (42). The $72-5$ cladding is still protecting the tubes, so that there is nc immediate danger, but at the present rate tho cladding will soon be gone. D PIle, for example, has already lost what may be as much as 50 percent of the 72.-S lejer in the first elght feet of some of its tubes (4I).

Since this corrosion is occurring in the cold, inactive portions of the tubss, pile operating varlables, such as power level, have no effect, The flow laboratory has characteristics of the process havo been olucidated.

1. It has boen conoluelvoly demonotrated that the probabllity of barnacle formatfon fo vory greatiy deoreased in the prosence of $2 \mathrm{ppm}$ sodium diohromato $(4,45)$. Proliminary data Indioato also that this offoct poraloto down to oonoontration of $0.1 \mathrm{ppm}$ and that intermittent dosages of $2 \mathrm{ppm}$ aro
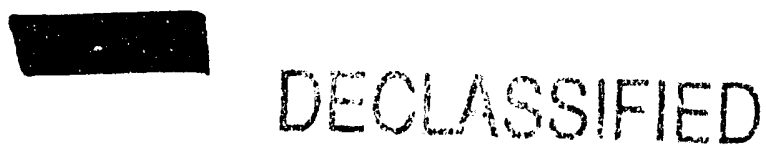


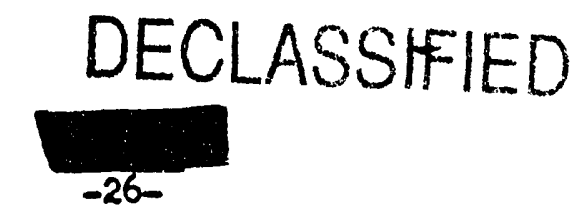

HW -2758

also effegflve, particularls'if a protreatment of contimuous feed 18 appliod $(45)$.

2. Barnacles may possibly be Instiutod by omalf forelgn particles in the vater, though this is certainly not a major source (4f).

3. The probability of barnacle formation 1ncreases with decreasing $\mathrm{pH}$, with decirasing temperature, and with decroasing flow rates $(44,46)$.

4. The presence of grephite foudur in a tube seetion greatlj fincroascs the prokability of barnaclo formation.

5. There 1s a marked tendency for bamacles to develop in mechanlcally produced defocts and in exial linos in the tubes whlch apparently are associated with the extrusion process.

6. P1ts under barnacles usually penetrate the 72-S lajer but stop at the 72-S - 2-S 1pterface. The character of the p1ts 18 typical of oxygen cell corroo10n $(4 \mathrm{i})$.

A fulls satiofactors description of the barnacle formation process has not yet been dereloped, but certain phases are clear. The derolopment of a barnacle eresumnbly beglns with the estabilshent of a local cell, with a very small anode. In slowly moving water, the corrosion product builds up over the ancdic spot, but not surf1clentiy close to provent some access of water. Once started in this manner, the corrosion product bullt up protocts the solution bathing the anode so that the oxjgen concentration 1s rapldiy roduced and malntained vel; bolow that of the bulk vater: an oxygen concentration cell is set up and the mounc. grows rapldy to 1 ts equilibrlum 8120. The means by which the originel cell is ast if are obscure, though several mechanisms have beon suggested?

1. Inhomogeneities in the oxygen concentration, arlsing from the Now patterns.

2. A galvanio cell, arleing from heavy-metels plating out of the process stroam.

3. A differential oxygen concentration cell, arfsing from inhomogenelties in the deposition film.

4. A galvunto cell arloling from graphltio streaks in the tube surface introduced in the fabrication process where graphito is employed as an extrusion lubricant.

5. Iocal anodes dovoloped by select1vo locel attack on the cxdde coat by the chloride Ions in the vater.

Any or all of these mechantems, or some other unsuspected Impurity in tine rater colld be responelblo. One might prodset that of the offocts listod would be repressed by sodium dichromate. Flnelly, it must bo pointed out that dichromate does not completoly provent front tube corrosinn, but does greatly decrease the severfty, to the point where the attack does not appear to be dangerous.

The most recent front tube 1nepections show that the sampling proeedare used heretofore does not give a quantitatire pleture of whole piles, consequentiy it is impossible to make sumarizing statomesits concerning the overall status of tise damage due to front tubo corrosion. It is cortalnly true, howerer, that mang opecific tubes have been damaged to a dangerous extent and that some of the piles are in bed stato.
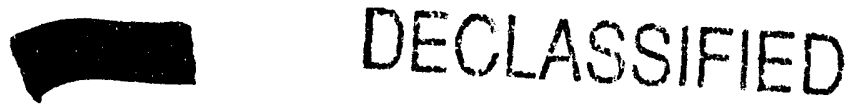


\section{SLUG CORROSION}

In the case of the slug rupturo problem, the oituation is not nearly as otraightforward as it 18 for the barnacle problem. Information developed in the last year, makes it appear that much of the slug rupturo problem mas bo unrelated to corrosion, but moy arlse from varlations in the quality of the heary metal and varlations in the canning process (47). These factors make it extremely diffleilt to determine what connection there is between ruptures and corrosion; consequently correlations with water quality cannot, in general, be established. However, It must be assumed that corrosion 18 an important factor. Proliminary concluslons from a surver of information concerning the actual distribution of thickness in can walls indicato that thero may be a regular increase in rupture frequency with corrosion rate, although this frequency, at present corrosion rates, 18 very much less than the overall rupture rate $(48)$. This conclusion is based on the ocourrence and degree of 1 - Si penetration into the can wall. Further, the probability that a plt will develop over any particular area of penetration 18 slight, but the probabilit that a pit and an Al-Si penetration site will run into each other increases rapldiy with pit depth, due to the Increased frequency of Al-Si spots of lesser depth. This again supports the proposition that it is oltal to prevent even relatively mild pitting.

As far as the unfform corrosion rato 18 concerned, there are as yet no date arailable from PT-105-9-P to confirm or deny the results of the dichromate elimination test, at least for ferric sulfate coagulated water. The extrapolation of the test results to alum water does not, however, appear to have been justified, since no appriclable difference has been observed to dete in the correslon rate in clim water with or without dichromate (46). The corrosion rate for alum treatod water with or without dichromate 1s substantialiy below that for Ferrifloc water elther with or without dichromate.

Some time after the elimination of dichromate, the moet serlous corrosion problem jet obsurvod in the plles appeared in the forpp of a severo slug pltting attack, accompanted. by a very high rupture rate, at F P1le $(49)$.

Three causes have been suggestod as being responstble for this attacks

1. Mercury Corrosion. While sources of mercury contamination have been detected both in the 100 and 300 Areas, it is difficult to account for the F P1le specificlty on such an hypothesis. Mercury has, however, been detected in pitted areas. Proliminary investigations have shown that it is unlikely that mereury can cause $F$ type pits under p1lo flors concistions $(45)$ and that $2 \mathrm{ppm}$ dichromate inhibits mercury attack on aluminum in any event $(42)$.

2. Cavitation. Considerable work has been dune by the P1le Coolant Erfects group on the production of carltation in process tubes. Conclusions to date are that unreasonably high restrictions of the anmulus and Improbably low pressures are required for carltation to occur in the p1le (45).

3. Erosion-corrosion Rocentiy there has come to light a plcture from one of the CNA roporto(50) deplcting olugs which show pitting olmilar in all rospooto to that produoed in 8 P110. Thl attaok ocoursed during runs which had addod turbldit10s, 0.g. diatomaceous oarth, Columbla R1rer sand, oto. CMX, at the timo, oarly 1944, was contomplating tho use of a continuous food of artificial turbidity for control of F1Im, and a detalled study was mado of this orosive

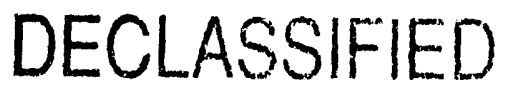




\section{DECLASSIEIED}

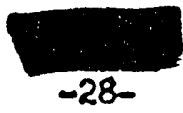

HW-2' 158

attack. It was found that the attack was strongly temperature dependent, Indicating that the corrosion was chemical and that the function of the abrasive was the removal of any protect1ve oxdde coat. It was also found that $2 \mathrm{ppm}$ sodium dichromate completely inhibited the attack at any pH betweon 6.5 and 8.0. Recent.ly a serles of jet impingement tests have com-.

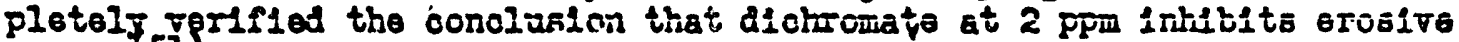
attack (51), and have shown that down to a concentration of $0.5 \mathrm{ppm}$ dichromate rotalns this inhlbiting power. Currentiy, mock-up iuns tests aro in progress to study the phenomena rarther. A number of terits which were run In the carltation study gave erldence of $F$ type pitting, vat it now appears that, in overy case where the attack was observed, it was due to turbldity from heat exchanger scales. Although it has been possible to make some correlation of the attack with $F$ P Ile turbidity $(45)$, it cannot be said that the nature of I P1lo attack 1s known. It 1s, for example, possible that afr bubbles can produce the same effect as turbldity. In any orent, the d1s.appearance of the attack at $F$ P1lo seems to be assoclated with the lower prevaling Fiver water temperature, so this particular type of attack would not be expectod again until next ounmer. On the other hand, there is no good reason for not expecting it again at $P$ P1lo or at the other arans currently not using dichromato. As a mattgr pf fact, slugs with $F$ typo plts have show up in both the $B$ and $A$ reactors $(52)$.

\section{CONCLUSTONS}

The decision to abandon dichromate was based on an exporiment of limited scope that: provided date only for a restrlcted set of conditions. There was a large anount of dita from oaris experiments indicating that, under certain clrcumstances, which well might ar130 in a Hanford p1lo, pltting would occur in uninhibited water. Operational. experferco, eince the olimination of dichromato, has shown that pit-producing cond1tions can and do occur in the actual piles with present mothods of operation, as prodicted by the early data. 11 of the arallable Information strongly Indicates that dichromate will alleviate the severity of this pitting. Ont1l such time as the piles can be operated strlctly within the confines of a sot of conditions which are known to by safo from pitting, the insuranco proolded by dichromate will probably be necessary".

Within. the framework of a dichromate Inhibltod oystom 1t should be possiblo to effect significant improvements in water quality and at least some roductions in cont. In all of the information revlewed thero 18 nothing to suggest that a concentration of $2 \mathrm{ppm}$ of sodium dichromate 1s the opt1mum, and there are strong Indications that good inhibition will bo obtalned at concentrations in the tenths of parts per mililion range. In view of the fact that the actual concentration is largoly arbitrary, there is clearly no reason for requiring the close limits of 1.8 to $2.2 \mathrm{ppm}$ previously in effect, and it is likels that considerable savings in operating costs could be made if these Iimits were broadened. So long as the composito daily average rate of addition falls in the range 1.8 to $2.2 \mathrm{ppm}$, the 1nstantaneous limfts need be no narrower than 1.0 to $3.0 \mathrm{ppm}$.

In aldition, thore 1s a good possiblilty that dichromato will not undorgo radiation reduction at a $\mathrm{pH}$ as low as 7.0. If experlmente currontis in progross show this to bo the case, and provlded it can be ohoun that dichromato will successfully inhlbit pitting tondencles at the lower pll under ootual operating conditions, then the need
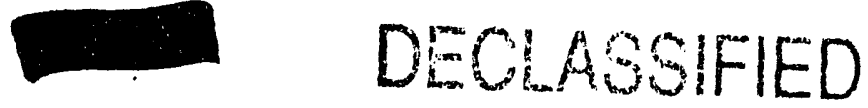
for $\mathrm{pH}$ adjustment will bo obvlatod, I1me add1tions can be ellmfnated, and the resulting water should produce algniflcantly lower corrosion rato.

It is clear that dichromato is not a completely sat1sfactory inhlbitor, though it is far better than no inhibitor under prosent conditions. Thls means that the speclfic causes of the corrosion problems in the p1le should be sought and ellminated where possible. If such causes cannot bo oliminatod, there 1s alwers the chance that thero are more effectire ways of lifing with them in bafoty than oy ading sodium dichromate. But the 1mportance of knowing the dangers 10 no greater than the importance of knowlng preclsely how to deal wh them.

The current operation of the p1les under PT-105-513-E(53) represents the most hopernl expedient fnr defining the conditions which will be sefs or thout the addition of dichromate and for 18olating the effects of the varlables which are Important 1r. the corrosion processes now occurring in the plles.

\section{Specific conclusions are as follows:}

a. Hater precess speciflcations ohould be changed to 1nclude the addition of $2 \mathrm{ppm}$ $\mathrm{Na}_{2} \mathrm{Cr}_{2} \mathrm{O}$ - $2 \mathrm{H}_{2} \mathrm{O}$ to process vetor. Control IImlts should bo 1.0 to $3.0 \mathrm{ppm} 80$ long as the average rato 18 within the rango 1.8 to $2.2 \mathrm{gpm}$

b. Hith the restrictions noted in $0, d$, and $0, P T-105-513-B(53)$, which now has $D$, $D R$, and C Plles operating with dichromato addition and B, H, and F without, should be permitted to continue, since $1 t$ will provlde reasonabio data.for a decision. concerning the setuel value of dietromato under present cunditions.

c. Before the roturn of hlgh river vater temperatures, the desirability of continuling PT-105-513-E anchonged : 111 hars to to 10 -ovaiuatod in tino Iight of laboratory data thasn arallablo concerning the nature of the attack noted at F P1le in the summer of 1952. Upon an prlor rocurrence of this type of attack, 1mmediato cinslderetion should be glion to adding dichromato at ail areas.

d. Due caution should be oxerclaed in interpretinf the rosults of PT-105-513-T, with reference to the use of dichromate; in particule ?:

1. The minimum time that the test mast or 1s one year; even then account must of the river from yoar to year.

2. The effects of changing other varis and dotalled consideratiop. For o: of chlorine foed rates (57) marks the be considered to have begun.
- to produce meaningful results in of varlations in the character

- ihe process must be given a rull - the recent change in the control sual date on which the year should

e. The purging not necessary to remove $11 \mathrm{~lm}$, currently being carrled out under PT-105-513-E*, should be stopped immediatoly, at least in the areas where dichromate is not being added. Such purging serros no usefur purpose and is potontiall. very dangerous.

- Whon PT-105-513-E was 1n1t!ated, there worn meagro indicatione that purging ciraln1shod rront tube corrosion. C, DR, and F P1I0s aro prosently being purgod on a rogular ochendule, though cosonisialis no prosaure drop I1In 18 ordinarliy formod froin the alum coagulated water 18 use in these reactors. Brperlmerts in tho flow laboratorg have demonotratod that purging 18 not a significant variablo in the front tube corrosion process.

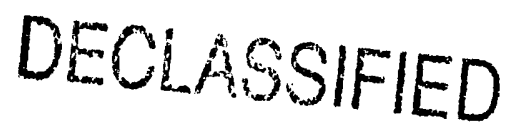




\section{DECLASSIFIED *

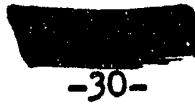

HW-27158

f. From the polnt of view of corrosion, the best avallable vater appeare to be alum coagulated, $\mathrm{pH}$ unadjusted or adjusted to somenhere in the range 6.5 to 7.5 , and sodium dichromate added at a concentration in the neighborhood or 2.0 ppm or less. Vigorous efforts are presently being expended to dotermines

1. The opt1mum concentration of sodium dichromato to be added.

2. Tho minimum $\mathrm{pH}$ which will bo sefo for pltting attack and for dichromato roduction.

8. In Investigation of the polarity relationships in operating pile tubes should be made with the end in Fiex of eraluat1ng the orerall desirablilty of 72-3 clad tubes, with particular reference to vater quallty.

h. Future resoarch should also includes

1. An Investigation to determine the effect of the fabrication process on front tube corrosion.

2. An investigation to determine the feasiblilty of preventing front tube corrosion by the use of sacriflcial perfs.

3. An Investigation of the effects of velocity on the minimum inhibitor concentration.

4. In Investigation of the feasibllity of new Inhibitors.

5. A study of the corrosive offect of speciflc impurities in the water, e.g., Is the chloride $10 n$ now belng added responsible for front tube cerrosion.

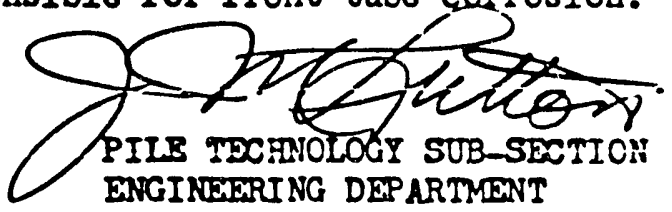

JM Luttonsmc 


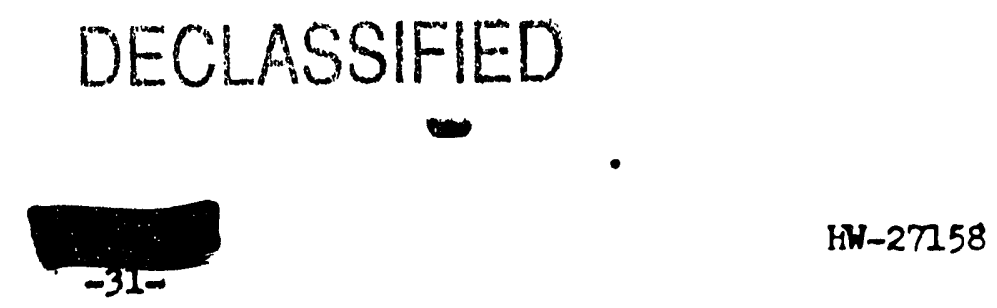

\section{BIBLTOGRAPH:}

1. H, R. Conley, "A Roviow of Water Treatment Technology as Applied in the 100 Areas - Hanford Horks", Bu-20342, 1-23-51.

2. R. J. Shields, interim Report, PT-105-9-P, PT-105-103-P, PT-105-362-P, Corrosion of Slugs", RA-24134, 4-18-52.

3. C. P. KIdder, "CMa - Final Roport", 7-4444, 7-31-46.

4. C. W. Botsford and R. D. Schilining, "A Reviow of Slug Corrosion as Related to Process Hater Composition and FIIn Formation in the Hanford Reactors", HW-23608, 3-17-52.

5. R. M. Fryar, "Irlp Report - Alcoa Rosearch Iaboratories", HH-21079, 5-10-51.

6. J. E. Draley, "Observations on Alumt num Corrosion at Hanfordn, ANL-FF-236C, 11-12-51.

-7. R. M. Fryar, "Proposed Treatment Process for 100 Area Water Plants", HW-23742, 3-10-52.

8. H. Worth1ngton, "Cosnments on CNa Weekly Roport 11-23-43 to 12-4-43", 1-20-4h.:

9. R. E. Larson and M. J. Szulinskd, "Filn Formation in W' Annulus", CJ-2524, 1-10-45.

10. J. M. Atrood, "The Erfects or Sodium Dichromate in P1I0 Process Hater", HiH-21317, 6-11-51.

11. R. H. Purceli, "Final Roport, PT-105-453-P, Sodium Dichromate Elimination Tests", HH-24009, 4-10-52.

12. R. M. Fryar, "Process Recommendations for 100-C Area Process Water Treatment Method", BN-24403, 5-9-52.

13. H. H. Ohlig, "The Corrosion Handbook", John Wiley \& Sons, New York, 1948.

14. H. Worthingtoin, "Corrosion Inhibitors for 17uminum", DUH-1354, 6-7-44, DUH-1428, $0^{6-10-44 .}$

15. J. E. Draley and J. W. Arendt, G. C. Inglish, F. F. Story, M. M. Wainscott, R. W. Berger, "The Corrosion of Aluminum in Dilute Solutions: Laboratory Studies", CT-3027, 6-19-45.

16. R. B. Hoxeng, "Corrosion of Construotion Matorialo, Bonding Materiale, and Uranium

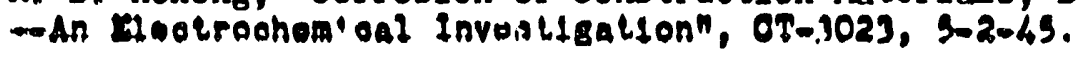

17. W. W. Binger, "Invest1gation of the Galvanio Corrosion of 304 Stainless Steel, 2-S iluminum and 72-S Aluminum", CT-3030, 6-2-45. 


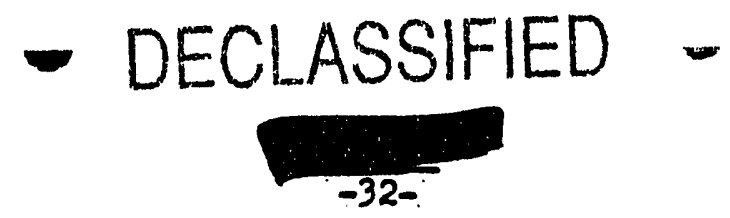

HN-27158

18. R. I. Iarson and M. J. Szulinshd, "Corros1on of Alumbum under 'W' P1le Cond1tions", CT-2550, 12-13-44.

19. R. B. Briggs; "Corrosion of Aluminum under W' P1le Conditions", CE-973, 10-9-43.

20. A. O. Allen and M. G. Bowman, N. Goldowskl, Ro, G. Larson, I. Treiman, "The Erfect

(- of Radistion on tho Corrosion of Motals by Hater", CO-1677, 7-6-i4.

21. W. P. Jesse, and M. C. Leverett, H.D.B., Spatz, $\dot{R}$. B. Briggo, "Corrosion and Aluminum Activity in P1lo Water", CT-1440, 5-15-4h.

22. S. Kuniansk and 0. Sisman, nffiect of P1lo Radiation on Corrosion Potent1als and Currents in 2-S - 72-S Colis!, CE-2055, 10-5-44.

23. R. B. Brlggs, "Radiation va. Corros1on", CE-2818, 4-7-45.

24. A. O. Alien and M. G. Bowmun, M. Burton, "Erfact or Radiation on Chromate in 'W' Water. I. Proliminary Roport", Cc-1746, 6-16-44.

25. C. P. XIdder, ONa Weokly Roports for $5 / 21-5 / 27 ; 5 / 28-6 / 3 ; 6 / 4-6 / 10 ; 6 / 11$ $6 / 17 ; 6 / 18-6 / 24 ; 6 / 25-7 / 1 ; 7 / 2-7 / 8 ; 7 / 9-7 / 15 ; 7 / 16-7 / 22 ; 7 / 23-7 / 29$; $7 / 30-8 / 5,1944$.

26. C. D. Kidder, CMX Weekly Report 7-9-44 to 7-i5-44, Cr. Bus No. 232.

27. I. A. Ghormlej, M. G. Domas, A. O. Allon, Mefrect of Raulation on Chromato in 'W' Water. IT. Experiments in CP-3 P1I0", CC-1966, 8-4-44.

28. M. G. Bowman, M. Burton, S. G. Dav1s, J. A. Ghormley, S. Gordon, weffect of Radiation on Chromate in Wator. III. Inhibition Experimente in the CP-3 P1Ie", CC-2099, 9-2-44.

29. A. O. Nlen, neffect of Radiation on Chromate in 'W' Water. IV. Further Considerations on Application of Proviously Reported Data to 'W' Comlitions", CC-2127, 9-8-44.

๑ 30. W. R. Conley, "S1I1ca Feed Elimination, PT-105-214-P, FInal Roport", HW-15943, $2-1-50$.

31. U. R. Rrans, Trans. Elect. Soc. 69, 213, (1936).

32. R. S. Delrymple, "Trip Report - March 9, 1951 through March 21, 1951", HW-20724, 4-4-51.

33. R. M. Fryar, "Tr1p Roport - 1lcoa Research Laborator1es", HW-21079, 5-10-51.

34. J. H. Bach, Nirtp Report - Conoultat1one on Aluminum Lliogs - Soptombor 6, 7, 21, and 12, 1951!, HM-22213, 9-21-51.

35. W. D. O1lbert, "Slug Corrosion Rates at Blevatod Temperatures, PT-105-103-P, Interim Roport No. 2n, HH-22548, 10-9-51. 


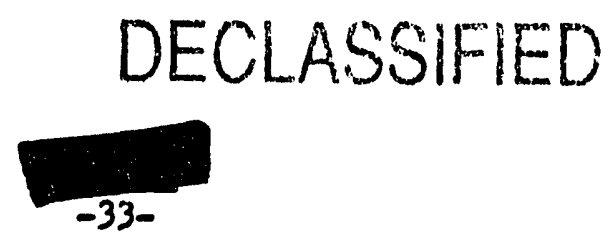

HW-27158

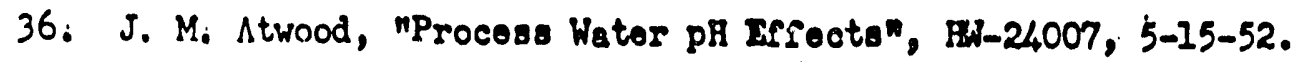

37. J. F. Sullivan, "Irxamination of the Inlet End of Process Tubes at B P110, PT-105-291-P, F1nal Roport", BH-19293, 10-30-50. Soe alboi. Mo. Iowls and 3. Coldemith, Filo Tost of Magnosium Front Drmm108, PT-105-407-P, Interlm Roport No. 1", HW-23083, 12-18-51.

38. R. G. Whesler, mprolcal Propert1es of Irradiatod Procese Iubing", iin-18725, 10-12-50.

3. A. B. Greninger; "milmination of Sod1um Dichromato from P1lo Process Water", IAN-24062, 4-8-52.

40. M. Low1s, "Technical Act1rit1ss Roport, P110 Coolant Effects - October 1952", HW-26012, 11-10-52.

4. K. R. DuHollander, "Interlm Roport, Front Tube Corrosion Problem", HW-26537, 12-20-53.

42. E. C. P1tier, NTóchn1cel Act1r1t10s Reports, Corrosion - November 1952, December 1952; January 2953", HW-26275, HN-26621, HW-26903, 12-10-52, 1-10-53, 2-10-53.

43. M. Low1s, "Toohnical Act171t1es Roport, P1lo Coolant Bffoots - November 1952", HW-26274, 12-1C-52.

44. M. Lowlo, "Tochn1cel 101171t10s Roport, P110 Coolant Effots - Dnoember 1952", BN-26620, .1-10-53.

45. M. Lowle, "Tochnical Act1v1t10s Roport, P110 Coolant Effects - January 1952", HW-26902, 2-10-53.

46. J. M. Atwood, "Tochnical Act171t1es Roport, Water Plant Development - December. $19.52^{n}$, Hij-26619, 1-10-53.

47. L. W. Lang, "Analys10 of Ruptured Slug Data", 9H-25177, 8-1-52.

48: S. Goldomith, Onpublishod data.

49. R. M. Fryar and W. R. Low1s, "Trip Roportn, BN-25602, 9-10-52.

50. C. P. KIdder, CMx Weekly Report for 1-9-44 to 1-16-44, cr Run No. 112.

51. W. C. Houck, "Tost of Water Qual1ty by Impingement", HA-26780, 1-8-53.

52. W. E. Foust, Private cormunication.

53. J. M. Atwood; "100 Areas Prooose Wator Qual1ty Evaluation Tosts, PT-105-513-En, HW-25978, 10-21-52.

54. C. P. KIdder, "ONX Wookly Roports", These roports wore 180 uod overy in $x$ from $8-21-43^{\circ}-8-28-43$ to $10-15-44-10-30-44$. 


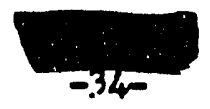

55. N. R. M11ler, "Summary and Correlation of Water Quality Testing Rosults", BN-27393, 3-23-53.

56. J. M. Atwood, "The Bffects of Ion pH Alim Hater on P1le Operation, PT-105-509-E, Supplement CW, . HH-2671.2, 12-31-52.

57. R. O. Mohann, "Process Water Chlorine 1dd1tion", MH-26795, 2-14-53.

(1)

(1)

3

-

-

(1)

-

0

(1) 

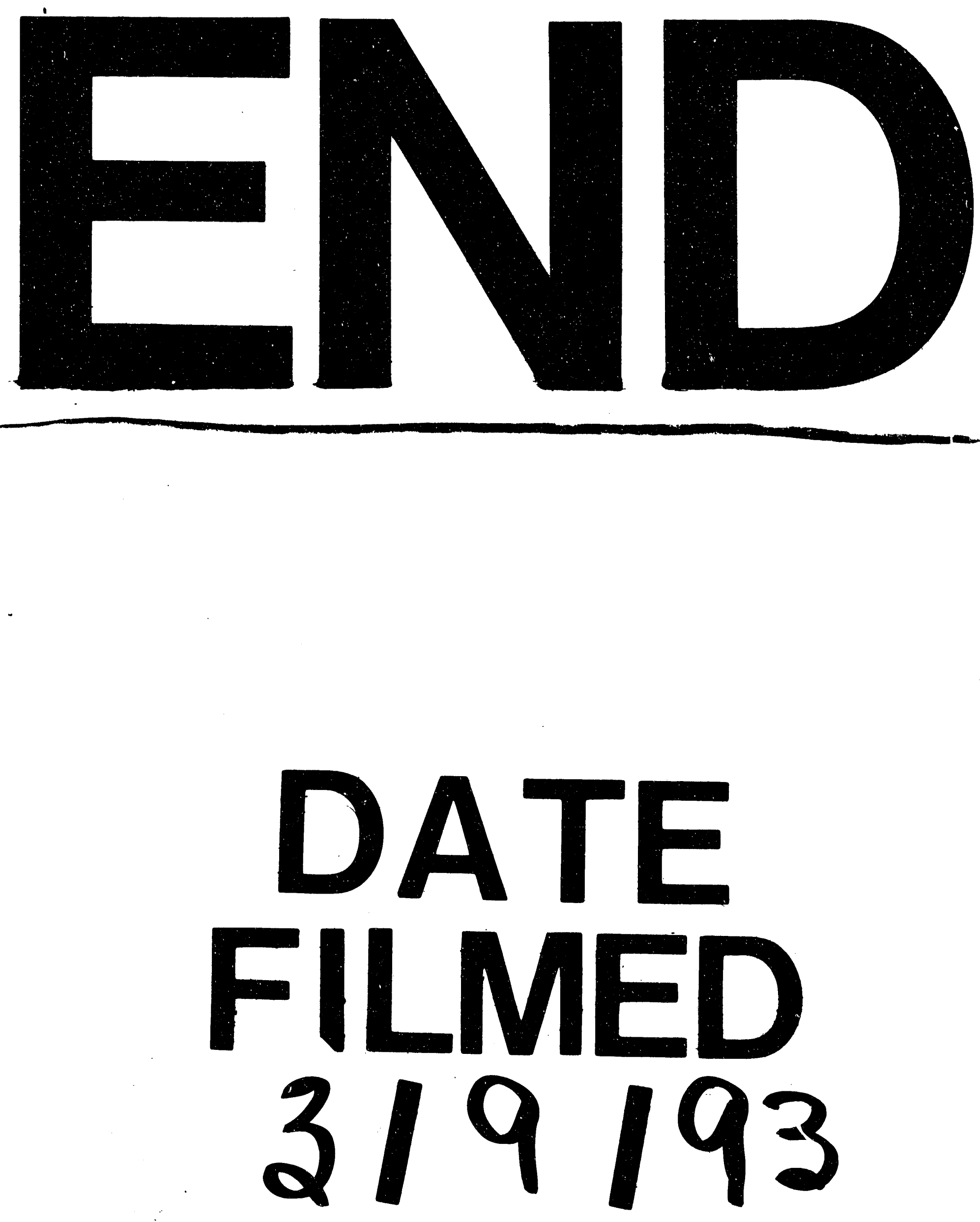
